\title{
II innovation for life
}

\section{Milieu-impact van twee verwerkingsroutes voor warme drankenbekers}

Vergisting en papierrecycling van karton-PLA koffiebekers

Tom Ligthart (TNO), Martien van den Oever (WFBR)

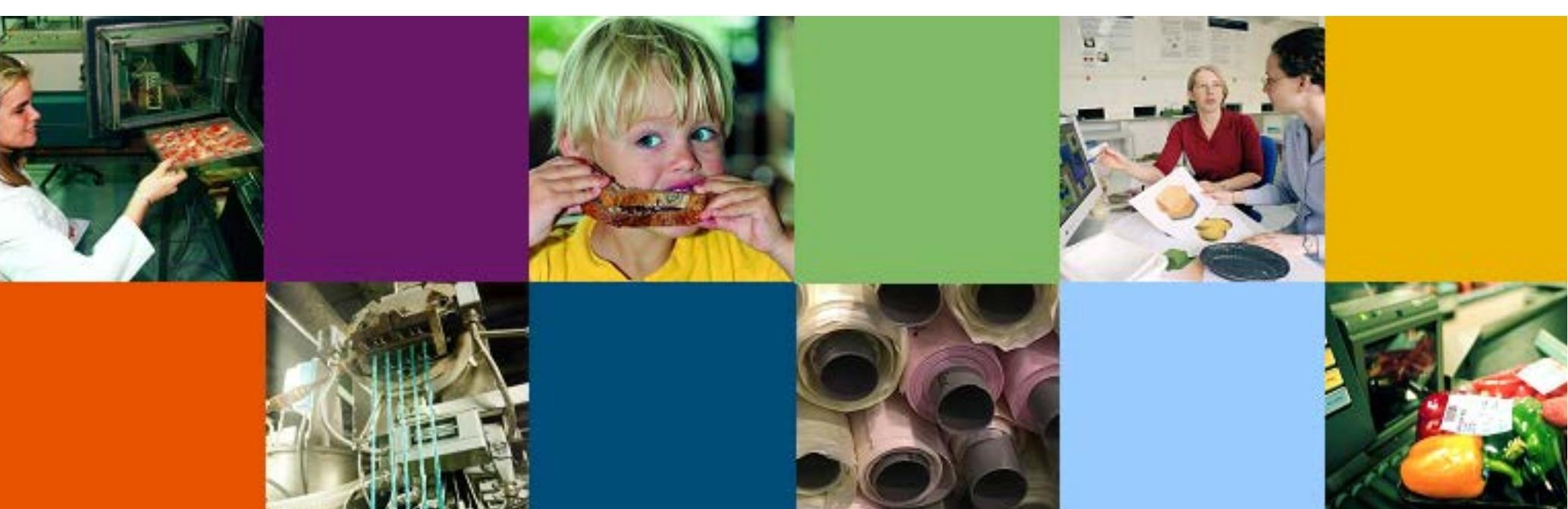





\section{Milieu-impact van twee verwerkingsroutes voor warme drankenbekers}

Vergisting en papierrecycling van karton-PLA koffiebekers

Tom Ligthart (TNO), Martien van den Oever (Wageningen FBR)

Rapport nr. 1792 



\section{Colofon}

Titel Milieu-impact van twee verwerkingsroutes voor warme drankenbekers - Vergisting en papierrecycling van karton-PLA koffiebekers

Auteur(s) Tom Ligthart (TNO), Martien van den Oever (Wageningen FBR)

Nummer Wageningen Food \& Biobased Research nummer 1792

ISBN-nummer ISBN nummer 978-94-6343-883-4

DOI https://doi.org/10.18174/434835

Publicatiedatum Februari 2018

Versie eindversie

Vertrouwelijk

Nee

OPD-code

Goedgekeurd door

Review

Jan Jetten

Naam reviewer

Financier Intern

Opdrachtgever

Harriëtte Bos (WFBR), Toon Ansems (TNO)

RVO.nl

RVO.nl

Wageningen Food \& Biobased Research

P.O. Box 17

NL-6700 AA Wageningen

Tel: +31 (0)317480084

E-mail: info.fbr@wur.nl

Internet: www.wur.nl/foodandbiobased-research

(C) Wageningen Food \& Biobased Research, instituut binnen de rechtspersoon Stichting Wageningen Research Alle rechten voorbehouden. Niets uit deze uitgave mag worden verveelvoudigd, opgeslagen in een geautomatiseerd gegevensbestand of openbaar gemaakt in enige vorm of op enige wijze, hetzij elektronisch, hetzij mechanisch, door fotokopieën, opnamen of enige andere manier, zonder voorafgaande schriftelijke toestemming van de uitgever. De uitgever aanvaardt geen aansprakelijkheid voor eventuele fouten of onvolkomenheden.

All rights reserved. No part of this publication may be reproduced, stored in a retrieval system of any nature, or transmitted, in any form or by any means, electronic, mechanical, photocopying, recording or otherwise, without the prior permission of the publisher. The publisher does not accept any liability for inaccuracies in this report. 


\section{Samenvatting}

De Rijksoverheid gebruikt op dit moment warmedrankenbekers gemaakt uit papiervezels met een coating van PLA. Tot begin 2017 werden deze bekertjes na gebruik nog in de afvalenergiecentrale (AEC) verwerkt. Maar per 1 mei 2017 is er een pilot gestart met twee verschillende manieren van afvalverwerking:

1. Collect a cup, waarbij de warmedrankenbekers door de firma Renewi (voorheen Van Gansewinkel) worden ingezameld en door papierfabriek WEPA Nederland B.V. (voorheen Van Houtum B.V.) worden verwerkt tot toiletpapier en tissues.

2. Vergisting en compostering, waarbij de warme drankenbekers door Attero worden vergist, waarbij biogas ontstaat en de rest wordt gecomposteerd tot compost.

De overheid wil inzicht in de duurzaamheid van deze beide verwerkingsroutes om een keuze te kunnen maken voor de meest duurzame. Wageningen Food and Biobased Research (WFBR) en TNO als onderaannemer hebben de opdracht gekregen om een studie uit te voeren waarin de milieu-impact van deze twee verwerkingsroutes voor warme drankenbekers worden vergeleken.

De milieu-evaluatie omvat voor alle alternatieven dezelfde vergelijkingsbasis, die de functionele eenheid wordt genoemd. Aangezien deze eenheid voor alle onderscheiden systemen gelijk is, waarborgt het zo een gelijkwaardige vergelijking. De functionele eenheid is hierna gedefinieerd.

\section{Functionele eenheid}

De inzameling, verwerking en recycling van 1000 door consumenten afgedankte koffiebekers, inclusief aanhangend vocht en vuil.

De functionele eenheid bevat dus 1000 schone koffiebekers met daarnaast het aanhangende vocht en vuil, zoals productresten.

Voor de milieu-evaluatie is de een veel gebruikte effectbeoordelingsmethode gebruikt: ReCiPe midpoints. Door deze methode te combineren met schaduwprijzen, die een milieueffect vertalen naar schade- ofwel schaduwkosten, kunnen alle milieueffectcategorieën worden uitgedrukt in een monetaire eenheid en daardoor kunnen de milieuprofielen van de alternatieven eenduidig met elkaar worden vergeleken. Vergeleken met ReCiPe endpoints, dat ook een geaggregeerde milieubelasting oplevert, is het voordeel dat deze methode waardevrij is en niet gebaseerd is op een waardeoordeel van een panel zoals voor de endpoints het geval is. Als alternatieve beoordelingsmethode is in dit rapport de Carbon footprint genomen vanwege de relevantie voor het beleid.

Uit de resultaten van de milieu-analyse blijkt dat bij evaluatie van het volledige milieuprofiel de recyclingroute het beste presteert met $€ 1,22$ vermeden milieukosten per 1000 bekers. Dit mede dankzij dat $89 \%$ van de ingezamelde koffiebekers geschikt wordt bevonden voor recycling. De 
bekers met teveel verontreiniging worden in de afvalenergiecentrale verwerkt, waar energie wordt teruggewonnen. De vergistingsroute neemt met een milieuprestatie van $€ 0,45$ vermeden milieukosten de tweede plaats in en presteert beter dan verwerking van afgedankte bekers in de AEC (€0,28 vermeden milieukosten).

Wanneer alleen naar het effect van klimaatverandering $\left(\mathrm{CO}_{2}\right.$ uitstoot) wordt gekeken presteert de vergistingsroute het beste met een vermijding van 5,4 kg CO 2 -eq. per 1000 ingezamelde bekers. Dit alternatief wordt gevolgd door achtereenvolgens de AEC en daarna de recyclingroute. De recyclingroute presteert bij de Carbon footprint het minst, omdat het vermijden van primaire papierpulp een relatief geringe winst voor klimaatverandering oplevert.

De komende $( \pm 3)$ jaren zijn voor gecoate kartonnen koffiebekers geen andere verwerkingsroutes op industriële schaal te verwachten dan de nu toegepaste en onderzochte: vergisten tot biogas en recyclen tot papier, naast verbranden in een AEC. Eveneens worden geen significante verbeteringen in de technologieën verwacht. Wel zijn er andere bio-based warmedrankenbekers op de markt waarvan de milieuimpact tijdens productie en in de afvalverwerkingsfase mogelijk concurrerend is. 


\section{Inhoudsopgave}

Samenvatting 4

1 Inleiding $\quad 7$

1.1 Doel en reikwijdte van het milieu-advies $\quad 7$

1.2 Leeswijzer 8

1.3 Functionele eenheid 8

1.4 Systeemgrenzen 9

1.5 Gebruikte LCA beoordelingsmethode 9

2 Recycling van koffiebekers 11

2.1 Inleiding 11

2.2 Inventarisatie sorteer- en recyclingsproces 11

3 Vergisting gevolgd door compostering van koffiebekers 14

$\begin{array}{lll}3.1 & \text { Inleiding } & 14\end{array}$

$\begin{array}{lll}3.2 & \text { Inventarisatie vergisting } & 14\end{array}$

4 LCA analyse en advies $\quad 17$

$\begin{array}{lll}4.1 & \text { Inleiding } & 17\end{array}$

4.2 Recycling van koffiebekers 17

4.3 Vergisting van koffiebekers 19

4.4 Vergelijking van de verwerkingsroutes 21

4.5 Gevoeligheidsanalyses 23

5 Potentiële andere verwerkingsroutes in ontwikkeling 27

$\begin{array}{lll}5.1 & \text { Karton-PLA versus karton-PE bekers } & 27\end{array}$

$\begin{array}{lll}5.2 & \text { Bio-based plastic koffiebekers } & 27\end{array}$

5.3 Biovezel versterkte/gevulde composieten 28

5.4 Vergisting en recycling 29

6 Conclusies en aanbevelingen 31

6.1 Levenscyclusanalyse 31

6.2 Alternatieve verwerkingsroutes 32

$\begin{array}{ll}\text { Literatuur } & 33\end{array}$

Lijst van afkortingen $\quad 35$

Bijlage A LCA netwerken $\quad 36$

Bijlage B Gekarakteriseerde resultaten verwerkingsroutes 43 


\section{Inleiding}

De Rijksoverheid gebruikt op diverse ministeries warme drankenbekers gemaakt uit papiervezels met een coating van PLA. Uiteindelijk zal de gehele Rijksoverheid overgaan naar een duurzame warme drankenbeker waar geen fossiele grondstoffen in zijn verwerkt. Tot eind maart 2017 werden deze bekers na gebruik nog via afvalverbranding verwerkt, maar per 1 mei 2017 is er een pilot gestart met twee verschillende manieren van afvalverwerking:

1. Collect a cup, waarbij de warme dranken bekers door de firma Renewi worden ingezameld en door papierfabriek WEPA Nederland B.V. worden omgezet naar toiletpapier en tissues.

2. Vergisting en compostering, waarbij de warme drankenbekers door Attero worden vergist waarbij biogas ontstaat en de rest wordt gecomposteerd tot compost.

De overheid wil inzicht in de duurzaamheid van deze beide verwerkingsroutes, teneinde een keus te maken voor de meest duurzame. Wageningen Food and Biobased Research en TNO Sustainability zijn daarom door RVO gevraagd een voorstel te maken voor een studie waarin de milieu-impact van deze twee verwerkingsroutes voor warme drankenbekers worden vergeleken.

\subsection{Doel en reikwijdte van het milieu-advies}

Het doel van deze studie is de Rijksoverheid duidelijkheid te geven over het milieuvoordeel van de recycling van koffiebekers ten opzichte van het verbranden van koffiebekers in een afvalenergiecentrale (AEC). Het voorliggende onderzoek is een milieukundige studie van de verwerking van kartonnen warmedrankenbekers afgedankt na gebruik door de consument. In het vervolg spreken we voor het gemak over koffiebekers, omdat koffie veruit de meest genuttigde warme drank is; echter in principe worden ook de overige warme dranken, aangeboden in dezelfde bekers, meegenomen. De studie omvat de milieueffecten van de inzameling van afgedankte koffiebekers, de verwerking daarvan en de milieuvoordelen van het vervangen van andere grondstoffen, door de inzet van secundair materiaal uit koffiebekers.

Hoofddoel van de studie is het vergelijken van de milieueffecten van inzameling via het restafval en verbranding in een AEC van koffiebekers met die van twee verschillende vormen van recycling. Het eerste alternatief is de recycling van de koffiebekers tot pulp, dat gebruikt wordt voor de productie van sanitair papier; hierdoor wordt de inzet van primaire sulfaatpulp vermeden. Het tweede alternatief is vergisting en compostering, waarbij het geproduceerde biogas de inzet van aardgas en/of door inzet in een WKK-installatie de Nederlandse mix van elektriciteit en warmte vermijdt. De te vergelijken alternatieven zijn dus:

1. Gescheiden inzameling gevolgd door sorteren en recycling van koffiebekers

2. Gescheiden inzameling gevolgd door vergisting en compostering van koffiebekers

3. Inzameling met restafval en verbranding in een AEC 
De productie van koffiebekers, voordat deze bij de consument terechtkomen, is niet opgenomen in de studie. Ook de productie van de warme dranken, die uit de koffiebekers worden gedronken, en het gebruik daarvan vallen buiten de scope van deze studie.

De milieuprestatie van deze drie varianten wordt door middel van de levenscyclusanalyse (LCA) vastgesteld; hierbij worden de ISO-normen voor LCA (ISO, 2006a, 2006b) als uitgangspunt genomen.

\subsection{Leeswijzer}

Een nadere toelichting op de systeemgrenzen, de functionele eenheid en de gebruikte LCA methode worden in de volgende paragrafen besproken. In de hoofdstukken 2 en 3 zijn de processen van respectievelijk de recycling en vergisting van koffiebekers beschreven. De berekende milieu-impact van de verwerkingsroutes met uitleg wordt gepresenteerd in hoofdstuk 4, evenals een onderlinge vergelijking en een vergelijking met verwerking in een AEC.

Naast de milieu-impact analyse van de karton-PLA koffiebekers, is een analyse gemaakt van de meest relevante ontwikkelingen van de verwerking van soortgelijke producten; een doorkijk over de komende 3 jaar is in hoofdstuk 5 gegeven.

Het rapport wordt afgesloten met conclusies en aanbevelingen.

Details van LCA netwerken en gekarakteriseerde milieu-impact waarden zijn samengevat in de bijlagen.

In dit rapport worden de volgende resultaten gepresenteerd:

- De milieuprestatie van de varianten voor de inzameling en verwerking van door de consument afgedankte koffiebekers;

- Een uitleg van de milieuprestatie van de varianten, zoals de bijdragen van onderliggende processen;

- Een onderlinge vergelijking van de varianten, waarbij die van verwerking in een afvalenergiecentrale als referentie dient.

\subsection{Functionele eenheid}

Centraal in de evaluatie van de verwerking van koffiebekers staat de functionele eenheid. Deze eenheid is voor alle te beschouwen systemen gelijk en waarborgt zo een gelijkwaardige vergelijking. De functionele eenheid is hierna gedefinieerd.

De inzameling, verwerking en recycling van 1000 door consumenten afgedankte koffiebekers, inclusief aanhangend vocht en vuil.

De functionele eenheid bevat dus 1000 schone koffiebekers en daarnaast het aanhangende vocht en vuil, zoals productresten. De koffiebekers bestaan voor $85 \%$ uit karton met aan de binnenzijde een coating van polymelkzuur (PLA, 14\% van de totale massa) en 1\% inkt (Pelican Rouge, 2017). Het PLA werkt als een effectieve vochtbarrière. Roerstaafjes en dergelijke vallen 
onder de noemer vocht en vuil. Daar de hoeveelheden vocht en vuil niet uit metingen bekend zijn, is een inschatting gemaakt op basis van een eerdere studie (Ligthart en Ansems, 2004). De voor deze studie gehanteerde waarden zijn respectievelijk 10\% en $20 \%$.

\subsection{Systeemgrenzen}

De milieu-evaluatie start op het moment, waarop een koffiebeker haar functie verliest. De milieubelasting van de beker zelf maakt dus geen deel uit van de milieuevaluatie. Productresten maken als 'vocht en vuil' wel deel uit van de studie. Het transport en de verwerking van 'vocht en vuil' na dit transport, zoals bijvoorbeeld in een waterzuivering, makkt ook deel uit van de milieuevaluatie.

Aspecten die binnen het systeem vallen, maar niet worden inbegrepen, zijn infrastructuur (gebouwen, machines en transportmiddelen zelf) en lange termijn emissies, die niet in de eerste honderd jaar na afdanking van de koffiebekers ontstaan. De redenen hiervoor zijn dat de lange termijn emissies een grote onzekerheid kennen; het uitsluiten van de infrastructuur is gebaseerd op de doorgaans geringe bijdrage, in termen van massa, aan de totale massabalans. Voor wat betreft de lange termijn emissies, dit speelt met name voor enkele achtergrondprocessen, wordt de onzekerheid verder vergroot doordat er geen zicht is op beheersmaatregelen van deze emissies op de lange termijn. Daarnaast wordt ook het transport van personeel, actief in de beschouwde systemen, niet meegenomen in de studie.

\subsection{Gebruikte LCA beoordelingsmethode}

Voor de milieu-evaluatie, ofwel effectbeoordeling, wordt gebruik gemaakt van de ReCiPe midpoints methode, waarbij de resultaten als enkelvoudige score worden getoond (Goedkoop et al., 2013). Deze ReCiPe methode heeft een zogenaamde midpoint benadering, waarbij de nadruk op de afzonderlijke milieueffecten ligt. De milieueffectcategorie wordt dan gepresenteerd in een eenheid die de milieudruk aangeeft. Voor klimaatverandering, bijvoorbeeld, is de eenheid $\mathrm{kg}$ $\mathrm{CO}_{2}$-equivalenten. Bij het gebruikmaken van de midpoint methode kan de milieubelasting in één getal worden uitgedrukt door het toepassen van zogenaamde schaduwprijzen (De Bruyn et al., 2017; Harmelen et al., 2006). Iedere milieueffectcategorie heeft zijn eigen schaduwprijs (zie Tabel 1), de schaduwprijzen geven de schade aan het milieu vertaald naar euro's ( $€$ ) aan. Vergeleken met ReCiPe endpoints, dat ook een geaggregeerde milieubelasting oplevert, is het voordeel dat deze methode waardevrij is en niet gebaseerd is op een waardeoordeel van een panel zoals voor de endpoints het geval is. 
Tabel 1 Schadumprijzen behorende bij de ReCiPe midpointmethode (De Bruyn et al., 2017).

\begin{tabular}{|l|l|r|}
\hline Effectcategorie & Eenheid & Schaduwprijs \\
\hline Klimaatverandering & $€ / \mathrm{kg} \mathrm{CO}$-eq. & $€ 0,057$ \\
\hline Aantasting ozonlaag & $€ / \mathrm{kg} \mathrm{CFC-eq.}$ & $€ 123$ \\
\hline Humane toxiciteit & $€ / \mathrm{kg} \mathrm{1,4DB-eq.}$ & $€ 0,158$ \\
\hline Fotochemische oxidantvorming & $€ / \mathrm{kg} \mathrm{NMVOC-eq.}$ & $€ 2,1$ \\
\hline Fijnstofvorming & $€ / \mathrm{kg} \mathrm{PM}$ 10-eq. & $€ 69$ \\
\hline Radiatie, ioniserende straling & $€ / \mathrm{kg} \mathrm{kBq} \mathrm{U235-eq.}$ & $€ 0,0473$ \\
\hline Verzuring, land & $€ / \mathrm{kg} \mathrm{SO}$-eq. & $€ 8,89$ \\
\hline Vermesting, zoetwater & $€ / \mathrm{kg} \mathrm{P-eq.}$ & $€ 1,9$ \\
\hline Vermesting, zoutwater & $€ / \mathrm{kg} \mathrm{N}$ & $€ 3,11$ \\
\hline Ecotoxiciteit, land & $€ / \mathrm{kg} \mathrm{1,4DB-eq.}$ & $€ 8,89$ \\
\hline Ecotoxiciteit, zoetwater & $€ / \mathrm{kg} \mathrm{1,4DB-eq.}$ & $€ 0,0369$ \\
\hline Ecotoxiciteit, zoutwater & $€ / \mathrm{kg} \mathrm{1,4DB-eq.}$ & $€ 0,00756$ \\
\hline Landgebruik & $€ /\left(\mathrm{m}^{2 \star j}\right.$ jaar) & $€ 0,037$ \\
\hline Landtransformatie & $\mathrm{m}^{2}$ & - \\
\hline Waterconsumptie & $\mathrm{m}^{3}$ & $€ 0,89^{\mathrm{a}}$ \\
\hline Uitputting, metalen & $\mathrm{kg} \mathrm{Fe}$ & - \\
\hline Uitputting, fossiel & $\mathrm{kg} \mathrm{olie}$ & - \\
\hline
\end{tabular}

${ }^{a}$ Voor uitputting van grondstoffen geven (De Bruyn et al., 2017) geen schaduwprijs, de prijs van $€ 0,89$ is afgeleid van de economische schade bij geïrrigeerde teelten.

Het systeem omvat ingaande en uitgaande stromen. Bij ingaande stromen moet worden gedacht aan het gebruik van grondstoffen, zoals mineralen, energiedragers en water. De uitgaande stromen betreffen de emissies naar bodem, water en lucht. In de onderhavige rapportage worden de geaggregeerde resultaten gepresenteerd, waarbij de vijf meest bijdragende effectcategorieën apart worden getoond. De niet-geaggregeerde resultaten worden in Bijlage B Gekarakteriseerde resultaten verwerkingsroutes gepresenteerd.

In de effectbeoordeling wordt de opname van kooldioxide door biogene processen, vastgelegd in het karton van de drankenkartons, en de latere emissie van de biogene kooldioxide, bijvoorbeeld bij verbranding, als klimaatneutraal beschouwd. Voor fossiel $\mathrm{CO}_{2}$ wordt een karakterisatiefactor van $1 \mathrm{~kg} \mathrm{CO}$-eq. gebruikt. Door deze wijze van modelleren worden de voordelen van energieterugwinning uit hernieuwbare grondstoffen, zoals dat in de AEC gebeurt, op een reële wijze meegenomen. Op verzoek van de opdrachtgever worden de resultaten ook gepresenteerd als een zogenaamde carbon footprint, waarbij alleen de effectcategorie 'Klimaatverandering' wordt beschouwd. 


\section{Recycling van koffiebekers}

\subsection{Inleiding}

Koffiebekers worden gemaakt van hoogwaardig karton en dit karton kan worden gerecycled tot nieuw karton of papier. WEPA Nederland B.V., het vroegere Van Houtum B.V., recyclet oud papier en karton, op haar locatie in Swalmen, tot sanitair papier zoals toiletpapier en handdoekjes. Als proef worden ook afgedankte koffiebekers afkomstig van de Rijksoverheid verwerkt. Recycling van koffiebekers vermijdt op de Nederlandse markt direct en indirect, doordat andere bronnen van oud papier en karton niet worden aangesproken, het gebruik van primaire pulp uit hout. De voor de milieuanalyse benodigde gegevens worden hierna besproken.

\subsection{Inventarisatie sorteer- en recyclingsproces}

Vanaf de hubs waar de ingezamelde bekers naar toe zijn gebracht, worden deze per vrachtwagen naar Destra, een onderdeel van Renewi dat onder meer oud papier en karton verwerkt, gebracht voor het uitsorteren van niet voor recycling geschikte bekers en van niet-beker materiaal. Daar bedrijfsspecifieke data over het sorteerproces ontbreken, is het sorteerproces voor oud papier en karton van ecoinvent ${ }^{1}$ gebruikt. Wel is voor dit proces de elektriciteit als afkomstig van het Nederlandse net gekozen. Van de ingezamelde bekers is gemiddeld 89\% volgens Destra geschikt voor recycling en wordt de resterende $11 \%$ afgekeurd. Deze laatste fractie wordt voor verdere verwerking getransporteerd naar de afvalenergiecentrale (AEC); zie Figuur 1. De afgekeurde stroom bevat bijvoorbeeld teveel vreemde materialen zoals verpakkingen. De bekers die geschikt zijn voor recycling worden per vrachtwagen naar WEPA getransporteerd. Aangezien meetgegevens over het percentage vocht en vuil niet voorhanden zijn, is geen onderscheid gemaakt in het gehalte vocht en vuil voor de goedgekeurde en de afgekeurde bekers.

1 "W aste paperboard, sorted \{Europe without Switzerland $\} \mid$ treatment of waste paperboard, sorting plant" 


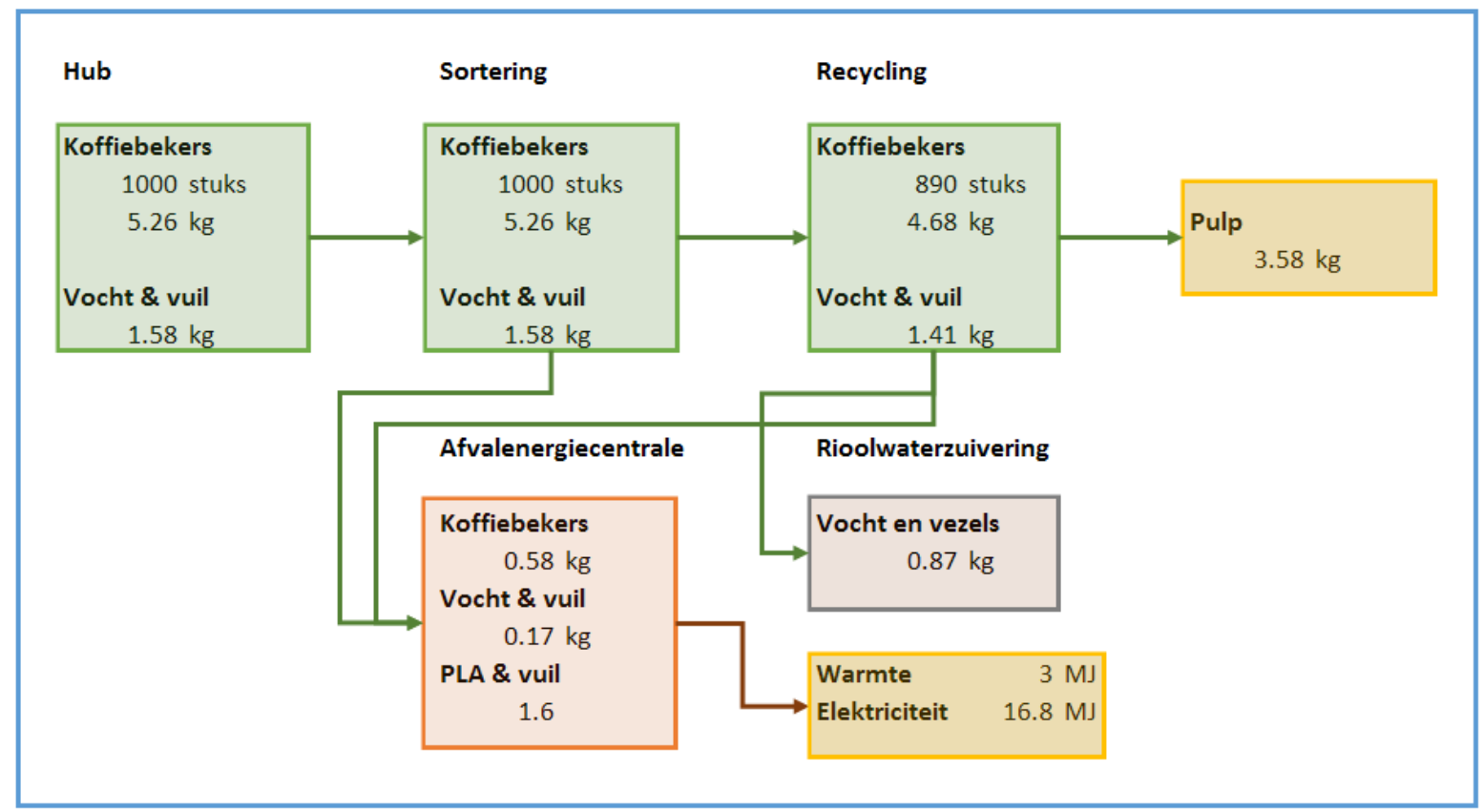

Figuur 1 Stroomschema recycling koffiebekers. Vermeden producten zijn in gele kaders weergegeven.

Bij WEPA worden de koffiebekers vanuit de opslag van het inkomende materiaal in de pulper gebracht, waar deze met proceswater, afkomstig uit het papierproces, worden gemixt tot een slurrie, waarin de kartonvezels zijn losgemaakt uit de bekers. Vervolgens vindt er een reiniging plaats met elders uit het papierproces teruggewonnen proceswater. WEPA wekt 7,5\% van de benodigde elektriciteit op met zonnepanelen (PV). De rest is gecertificeerde stroom van Noorse waterkrachtcentrales. Het elektriciteitsgebruik van de papiermachine is buiten beschouwing gelaten, omdat alleen de pulpbereiding zelf onderdeel van de analyse is. Zie verder Tabel 2. Aangenomen is dat het vocht en de niet teruggewonnen vezels $(10 \%)$ in de afvalwaterstroom terecht komen en verwerkt worden in de waterzuivering. De PLA coating wordt afgescheiden evenals het vaste vuil dat met de koffiebekers is meegekomen; deze twee stromen worden in de AEC verwerkt.

\section{Tabel 2 Inventarisatie recyclingproces WEPA.}

\begin{tabular}{|l|r|l|}
\hline Processtroom & Hoeveelheid & Eenheid \\
\hline Elektriciteit & 173.8 & $\mathrm{kWh} /$ ton \\
\hline Aandeel eigen fotovoltaïsch & 7,5 & $\%$ \\
\hline Proceswater & 4,0 & $\mathrm{~m}^{3} /$ ton \\
\hline Afvalwater naar RWZI & 4,0 & $\mathrm{~m}^{3} /$ ton \\
\hline Rejects & 10 & $\%$ \\
\hline
\end{tabular}

De transport afstanden zijn gebaseerd op een op full time equivalent (FTE) gewogen gemiddelde afstand tussen de locaties van overheidskantoren en Destra te Breda, waarbij er van uit is gegaan dat de afstand tussen kantoren en de hub gemiddeld $20 \mathrm{~km}$ is. Deze afstand van $20 \mathrm{~km}$ wordt 
voor de milieubelasting buiten beschouwing gelaten, daar de bestelwagens de bekers op een lege retourrit meenemen. De transportafstand naar Breda is op basis van $85 \%$ van het totaal aantal fte's $79.2 \mathrm{~km}$. De afstand tussen Destra en WEPA bedraagt $127 \mathrm{~km}$. Voor het transport naar de AEC, voor de verwerking van rejects, is een afstand van $75 \mathrm{~km}$ aangenomen. Door de energieterugwinning in de AEC wordt aan externe netten warmte en elektriciteit geleverd; dit vermijdt de conventionele opwekking van warmte (met aardgas) en elektriciteit (NL mix), zie Tabel 3.

Tabel 3 Door verbranding van $1 \mathrm{~kg}$ op huisvuil gelijkend afval, met een LHV van 9,45 MJ/ kg opgewelete vermeden energie $(M J)^{2}$.

\begin{tabular}{|l|r|}
\hline Vermeden energie & Hoeveelheid \\
\hline Electriciteit, hoogspanning $\{\mathrm{NL}\}$ & 1,98 \\
\hline Warmte, industrie/warmtenetten aardgas \{Europa\} & 0,36 \\
\hline Warmte, centraal/kleinschalig aardgas $\{$ Europa & 0,39 \\
\hline
\end{tabular}

${ }^{2}$ Gemiddelde stookwaarde van restafual gebaseerd op (Rijkswaterstaat, 2017) 


\section{$3 \quad$ Vergisting gevolgd door compostering van koffiebekers}

\subsection{Inleiding}

Het karton van koffiebekers kan ook, samen met het vocht en vuil, worden vergist. De vergisting levert biogas en digestaat op. Het digestaat wordt vervolgens gecomposteerd en levert dan compost op. Het biogas wordt soms opgewerkt tot zogenaamd groen gas, dat aardgas vervangt of het biogas wordt als brandstof in een warmtekrachtinstallatie gebruikt en dat levert warmte en elektriciteit op. De voor de milieuanalyse benodigde gegevens, die specifiek zijn voor de locatie Wijster van Attero, worden hierna besproken.

\subsection{Inventarisatie vergisting}

Vanaf de hubs waar de ingezamelde bekers naar toe zijn gebracht worden deze per vrachtwagen naar Attero in Wijster getransporteerd voor de vergisting van de bekers samen met het meegekomen vocht en vuil. Sortering is als tussenstap niet nodig, de bekers gaan via een tussenopslag direct de vergistingsinstallatie in. De biogasopbrengst van de vuile bekers is door middel van een proef vastgesteld en bedraagt gemiddeld $419 \mathrm{Nm}^{3} /$ ton met een methaangehalte van 51\% (OPure B.V., 2017). De te vergisten koffiebekers worden met aardgas voorverwarmd om het vergistingsproces te versnellen. In de vergistingstank worden de bekers en het vocht en vuil grotendeels omgezet in biogas, het niet vergiste deel en afgestorven micro-organismen vormen het digestaat, $322 \mathrm{~kg} /$ ton bekers (OPure B.V., 2017). Het digestaat van de warmedrankenbekers wordt vervolgens gecomposteerd, waarbij het voor $50 \%$ wordt omgezet in compost. Op basis van het bij Attero getoonde composteringsproces is aangenomen is dat de koffiebekers een verwaarloosbare hoeveelheid rejects geeft. Een overzicht van de massastromen is gegeven in Figuur 2. 


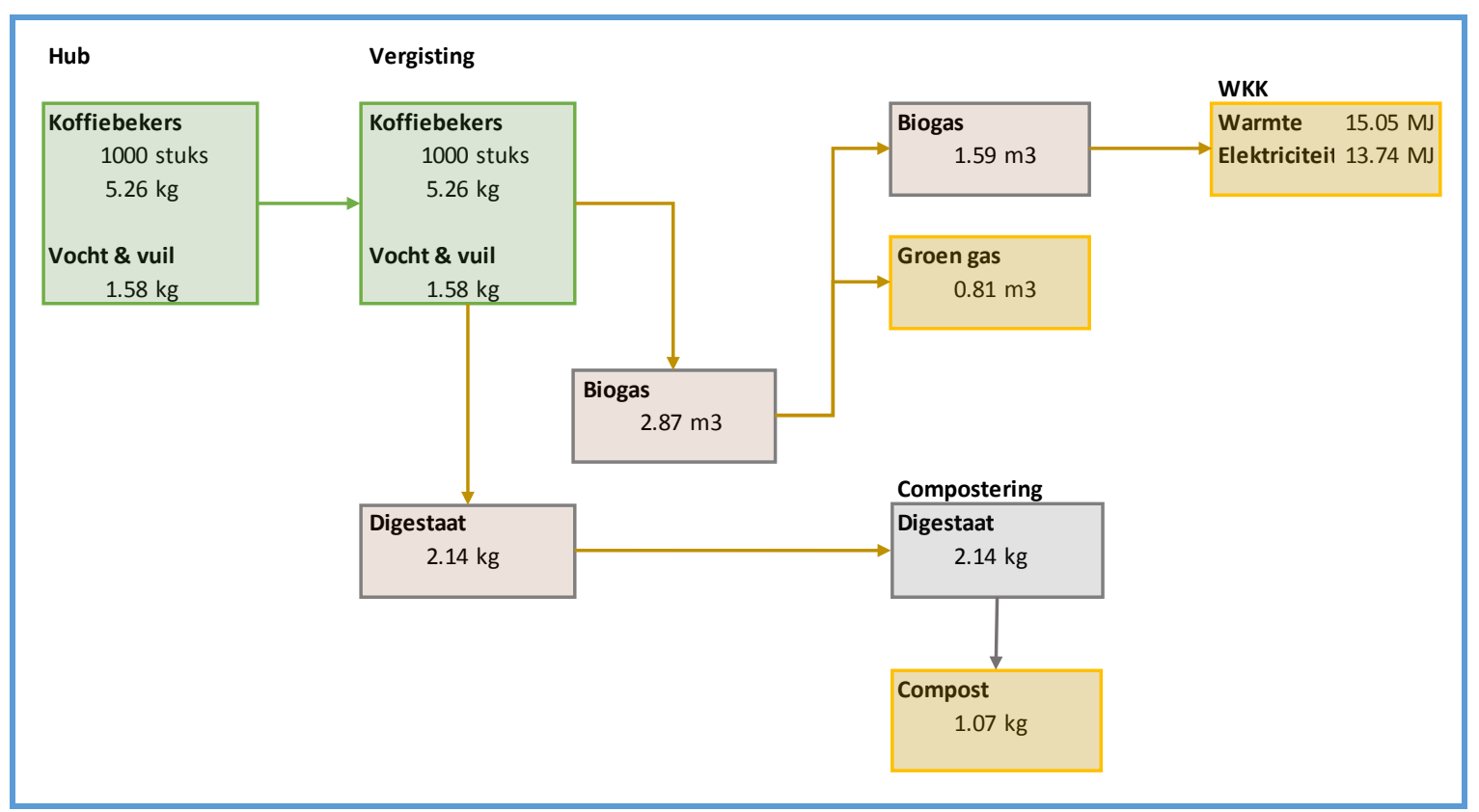

Figuur 2 Stroomschema voor de vergisting van afgedankte koffiebekers. Vermeden producten zijn in geel weergegeven.

Het biogas wordt voor een deel (55.3\%) gebruikt om in een warmtekrachtinstallatie te worden omgezet in elektriciteit en warmte ${ }^{3}$. Het betreft elektriciteit en warmte, die anders elders zouden moeten worden opgewekt. Het andere deel van het biogas wordt omgezet in groen gas, dat in het aardgasnet wordt gebracht en hiermee Nederlands aardgas vervangt. Daarbij wordt rekening gehouden met de andere calorische waarde van het biogas (20,65 MJ.Nm $\left.{ }^{-3}\right)$ ten opzichte van Nederlands aardgas $\left(31,65 \mathrm{MJ} . \mathrm{Nm}^{-3}\right)$. Daar het groen gas biogeen is, is de verbranding van dit gas $\mathrm{CO}_{2}$-neutraal; de daaraan gekoppelde milieuwinst is ook in de analyse meegenomen bij de vermeden producten.

De verwerking van het digestaat levert compost op, dat wordt ingezet als potgrond ( $90 \%)$ en als landbouwcompost (10\%). Inzet als potgrond vervangt veen als grondstof; bij de inzet in de landbouw wordt het aanwezige organische materiaal voor circa $30 \%$ vastgelegd als organisch koolstof in de bodem. De rest van de koolstof wordt door micro-organismen verademd, in de modellering van het broeikaseffect wordt kort-cyclisch $\mathrm{CO}_{2}$ als $\mathrm{CO}_{2}$-neutraal beschouwd, het verademde koolstof draagt daarom niet bij aan het broeikaseffect. In de studie van (BVOR \& IVAM, 2013), is voor de toepassing van compost als veenvervanger ook de vermeden $\mathrm{CO}_{2-}$ emissie van de afbraak van het veen meegenomen. De door hen gehanteerde waarde van $0.85 \mathrm{~kg}$ $\mathrm{CO}_{2} / \mathrm{kg}$ veen is ook hier gehanteerd. Voor toepassing als landbouwcompost uit koffiebekers is geen vermeden product opgenomen daar de N-P-K inhoud van compost gemaakt van het digestaat uit koffiebekers verwaarloosbare concentraties van deze nutriënten zal hebben.

\footnotetext{
${ }^{3}$ Voor de elektriciteitsopwek.king op de locatie Wijster is nitgegaan van $0.01074 \mathrm{~kg} C \mathrm{CO}_{2}-e q / \mathrm{MJ}$
} 
Evenals bij de recycling zijn de transportafstanden gebaseerd op een op FTE gewogen gemiddelde afstand tussen de locatie van de overheidskantoren en Attero te Wijster. De afstand tussen kantoren en de hub, gemiddeld $20 \mathrm{~km}$, is van de transportafstand naar Wijster afgetrokken en die komt daardoor op $100 \mathrm{~km}$. Dit omdat het transport met bestelwagens naar de hub toch al plaatsvindt en het meenemen van de afgedankte koffiebekers niet tot significant meer milieubelasting zal leiden. 


\section{$4 \quad$ LCA analyse en advies}

\subsection{Inleiding}

In dit hoofdstuk worden de resultaten van de milieuanalyse gepresenteerd. In eerste instantie worden de resultaten van de twee alternatieven afzonderlijk besproken, daarna wordt de vergelijking gemaakt. Bij het presenteren van de resultaten wordt een onderscheid in een drietal fasen gemaakt:

1. Transport van koffiebekers en afgeleide stromen

2. Verwerkingsproces (recycling, vergisting)

3. Vermeden producten

\subsection{Recycling van koffiebekers}

De totale milieubelasting, uitgedrukt in schaduwkosten bedraagt per 1000 bekers $-€ 1,22$. Het negatieve bedrag in Figuur 3 betekent, dat er sprake is van een milieuwinst bij de door recycling vermeden producten. Deze milieuwinst is het gevolg van het vermijden van de inzet van primaire pulp voor de fabricage van sanitair papier en van het vermijden van de inzet van primaire energie door energieterugwinning in de AEC. De bijdrage van de pulp is, vergeleken met de bijdrage van de energieterugwinning, relatief het grootst, doordat $89 \%$ van de bekers wordt gerecycled. In Bijlage A LCA netwerken is dit in meer detail te zien. De meeste winst komt van de milieueffecten 'Agricultural land occupation', 'Particulate matter formation' en 'Climate change'. Het sorteren en recyclen van de bekers heeft een veel grotere bijdrage aan de milieubelasting dan de transporten (zie Figuur 3). 


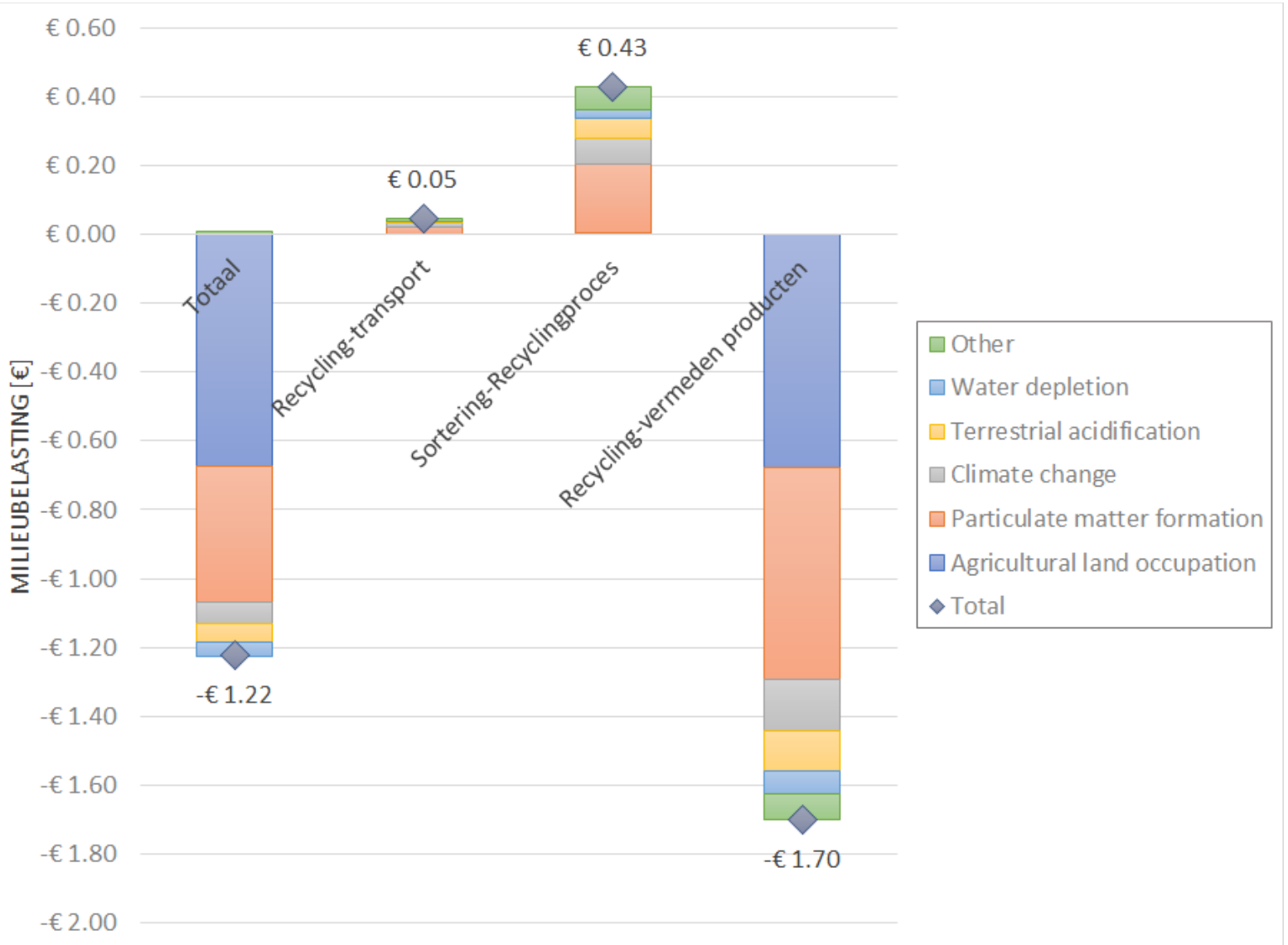

Figuur 3 Milieubelasting, nitgedrukt als schaduwkosten, van de recycling van 1000 warmedrankenbekers. De vijf meest bijdragende effectcategorië̈n zijn hierbij weergegeven.

De onderliggende processen die de milieuprestatie bepalen, zijn, wat betreft de processen die een bijdrage leveren aan de milieuwinst, in de aangegeven volgorde van belang: houtproductie, primair pulpproces, elektriciteitsopwekking en warmteproductie. De eerste twee processen zijn gekoppeld aan het vermijden van primaire pulp; de laatste twee aan de levering van elektriciteit en warmte door de AEC. De verbranding in de AEC van de niet voor recycling geschikte bekers heeft de grootste milieubelasting, gevolgd door het sorteerproces zelf. Hierbij moet wel worden opgemerkt dat dit ecoinvent proces betrekking heeft op het volledige sorteerproces van oud papier en karton en daardoor mogelijk tot een overschatting van de milieubelasting van dit proces leidt. De invloed van het transport van de bekers is, met een bijdrage van minder dan $5 \%$ aan het totaal, betrekkelijk klein. 


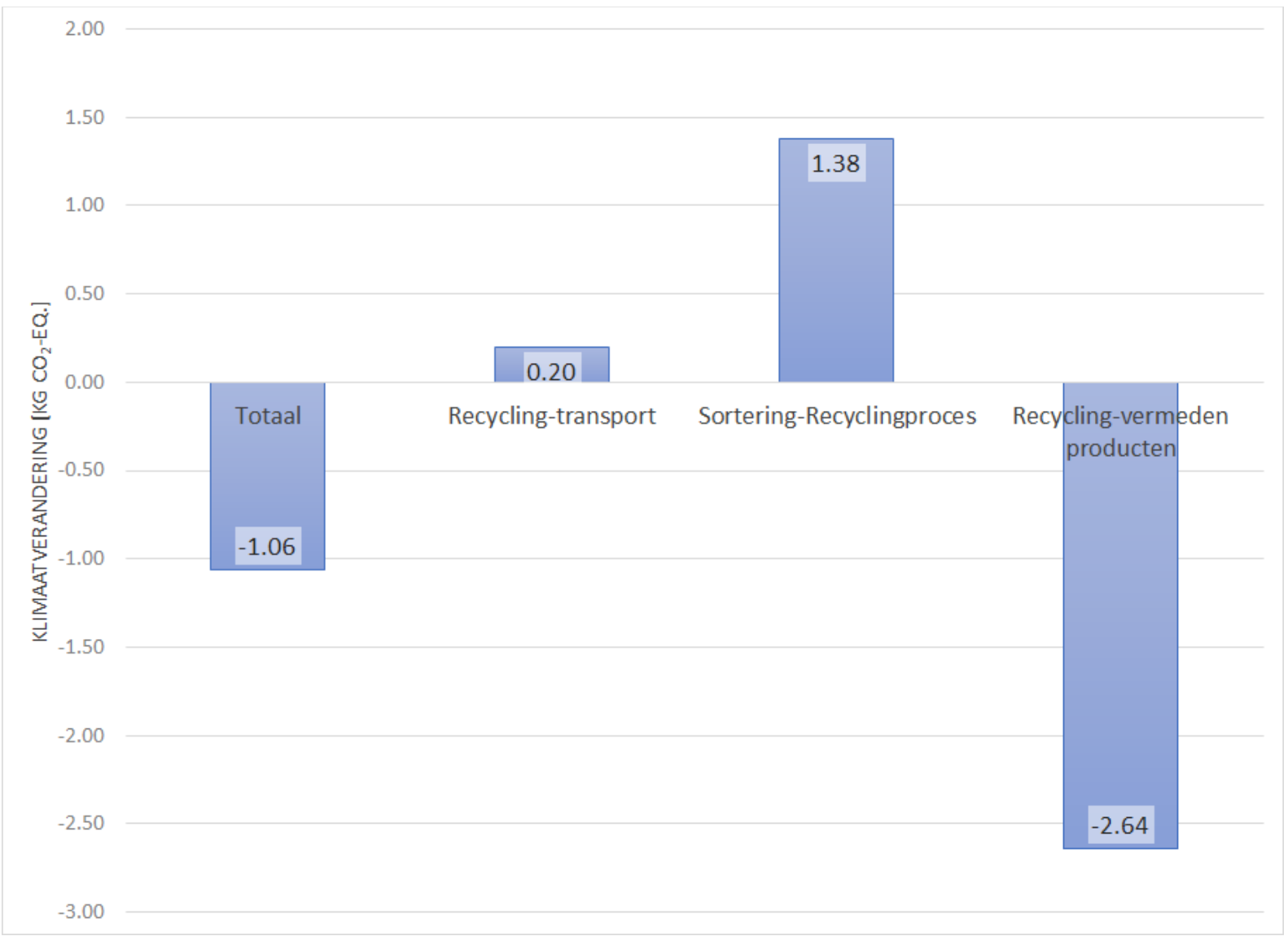

Figuur 4 Carbon footprint van de recycling van 1000 warmedrankenbekers.

Wanneer niet naar het volledige milieuprofiel wordt gekeken, maar wordt ingezoomd op klimaatverandering en deze wordt uitgedrukt in $\mathrm{CO}_{2}$-equivalenten krijgt men de zogenaamde Carbon footprint. In Figuur 4 is de Carbon footprint van de recycling van koffiebekers gepresenteerd. Ook nu is er sprake van een milieuwinst: $1,06 \mathrm{~kg} \mathrm{CO}_{2}$-eq. per 1000 ingezamelde bekers. De grootste bijdrage aan de milieuwinst is afkomstig van het vermeden elektriciteitsgebruik bij de productie van de (vermeden) primaire pulp. Daarnaast wordt er door de energieterugwinning van de AEC de conventionele productie van elektriciteit (NL mix) vermeden, zie hiervoor Figuur A-2 in Bijlage A. Daarmee wordt de uitstoot van fossiele koolstofdioxide en methaan vermeden, stoffen die bijdragen aan klimaatverandering.

\subsection{Vergisting van koffiebekers}

De vergisting van koffiebekers, gevolgd door compostering van het digestaat, levert een netto milieuvoordeel, uitgedrukt als schaduwprijs, op van $€ 0,45$ per 1000 ingezameld bekers (zie Figuur 5). De meeste milieuwinst is gerelateerd aan het vermijden van de uitstoot van broeikasgassen 'Climate change' en van fijnstof 'Particulate matter formation'. Het transport van de afgedankte bekers en de vergisting en compostering leiden tot een zekere milieubelasting en dan met name door de uitstoot van fijnstof en fijnstofvormende stoffen. 


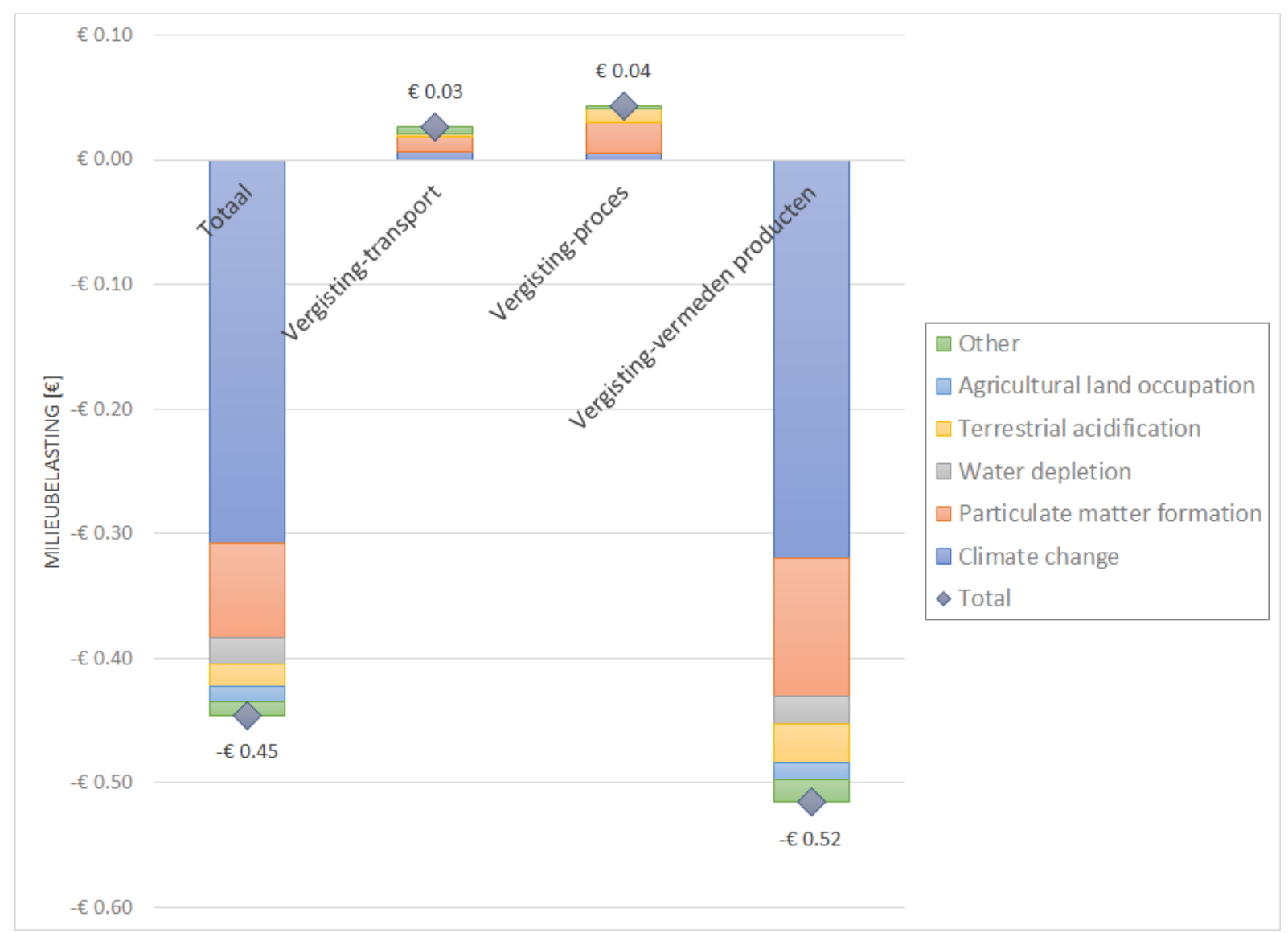

Figuur 5 Milieubelasting, uitgedrukt als schaduwkosten, van de vergisting van 1000 warmedrankenbekers.

De grootste milieuwinst wordt bereikt door het vermijden van conventionele elektriciteitsopwekking (Nederlandse mix), het vermijden van de uitstoot van fossiel $\mathrm{CO}_{2}$ ten gevolge van de verbranding van groen gas in plaats van aardgas en het vermijden van de inzet van fossiele brandstoffen bij de conventionele energieopwekking. Daarnaast draagt de vermeden emissie door compost in plaats van veen te gebruiken als potgrond bij aan de milieuwinst. Het elektriciteitsgebruik bij de vergisting en compostering geeft een zekere milieubelasting.

De Carbon footprint van de vergistingsroute laat een winst zien van 5,4 $\mathrm{kg} \mathrm{CO}$-eq. per 1000 ingezamelde bekers (zie Figuur 6). Ten opzichte van de vermeden producten hebben het transport en het vergistings- en composteringsproces een zeer geringe milieubelasting. De milieuwinst is het gevolg van de vermeden elektriciteits- en warmteproductie. Daarnaast speelt het vervangen van veen in potgrond door compost, met name de vermeden emissie van fossiel $\mathrm{CO}_{2}$ bij afbraak van het veen, een rol. 


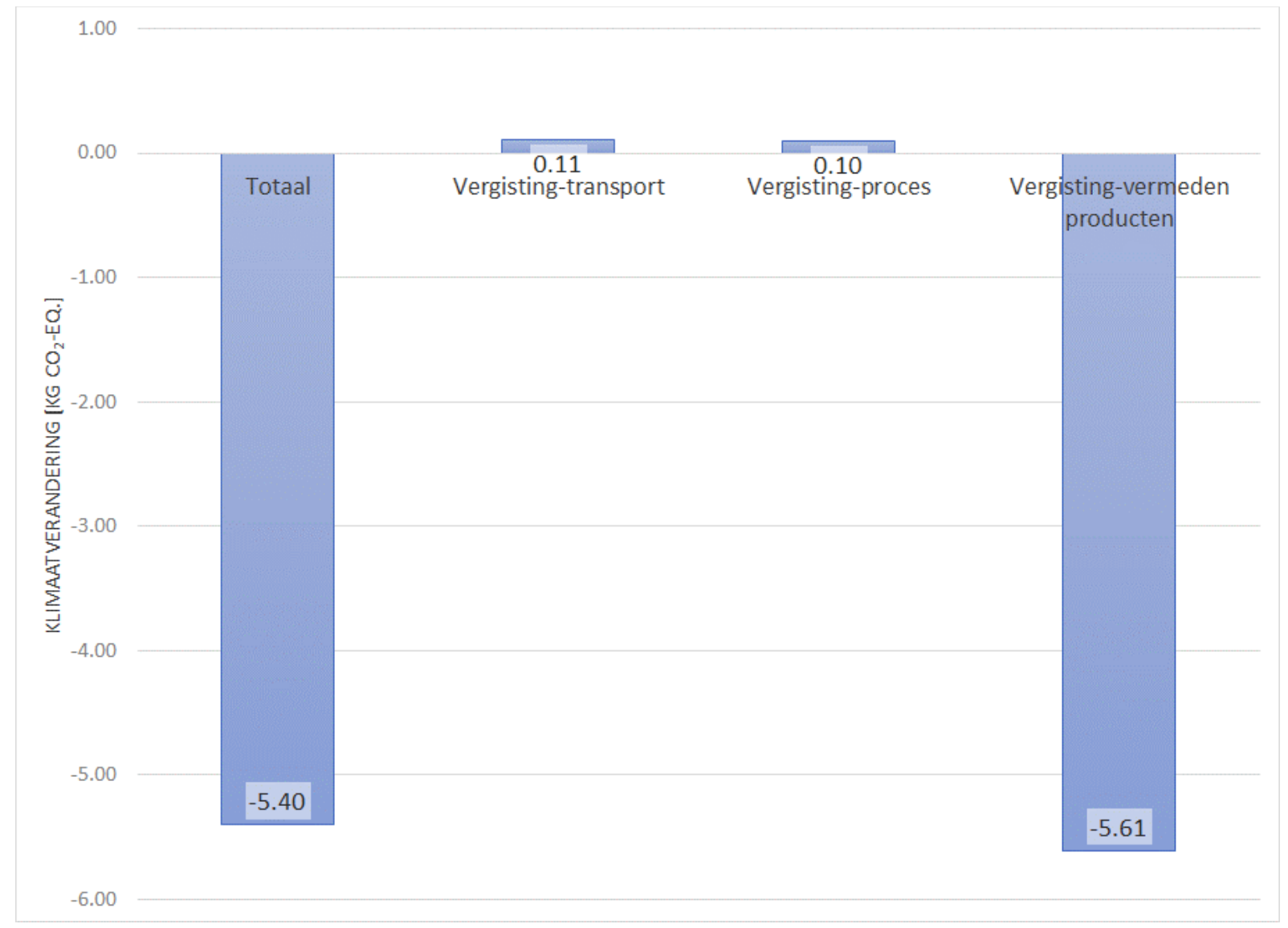

Figuur 6 Carbon footprint van de vergisting van 1000 warmedrankenbekers.

\subsection{Vergelijking van de verwerkingsroutes}

Bij het vergelijken van de twee verwerkingsroutes met de AEC als referentie, blijkt dat de recycling van warmedrankenbekers duidelijk een betere milieuprestatie heeft dan de vergistingsroute, zoals te zien is in Figuur 7. De AEC laat de minste milieuwinst zien. De goede prestatie van de recyclingroute is het gevolg van de relatief grote vermeden milieubelasting door de productie van secundaire pulp.

Wanneer echter de Carbon footprint als basis voor de vergelijking wordt gebruikt (Figuur 8), heeft de vergistingsroute veruit de beste prestatie. Deze prestatie van de vergistingsroute wordt veroorzaakt door het inzetten van groen gas, waarmee de uitstoot van fossiel $\mathrm{CO}_{2}$ door verbranding van aardgas wordt vermeden, en door de inzet van biogas in een WKK, waardoor de inzet van fossiele brandstoffen wordt vermeden. De AEC neemt qua Carbon footprint een positie in tussen de vergistings- en recyclingroute.

Bij de vergelijking van de drie routes moet worden opgemerkt dat de aanwezigheid van vocht en vuil met name voor de recyclingsroute kritisch is. Te hoge vervuiling, op basis van een visuele inspectie, van de zakken met bekers leidt tot afkeur voor verdere recycling. Voor de vergistingsroute, en zeker de AEC, is de mate van vervuiling minder kritisch. 


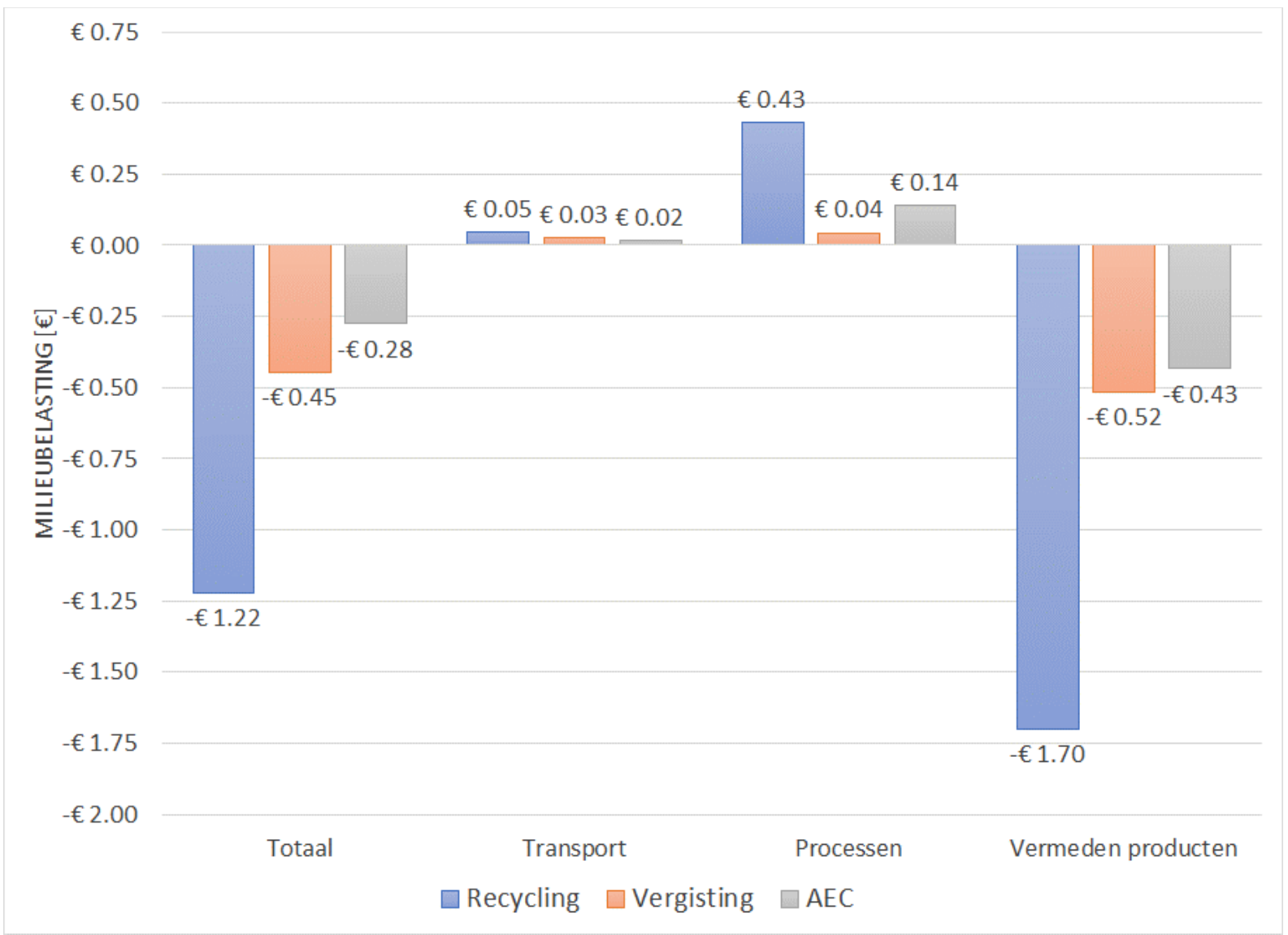

Figuur 7 Vergelijking milieubelasting als schaduwkosten van de recyclingroute, de vergistingsroute en de AEC. 


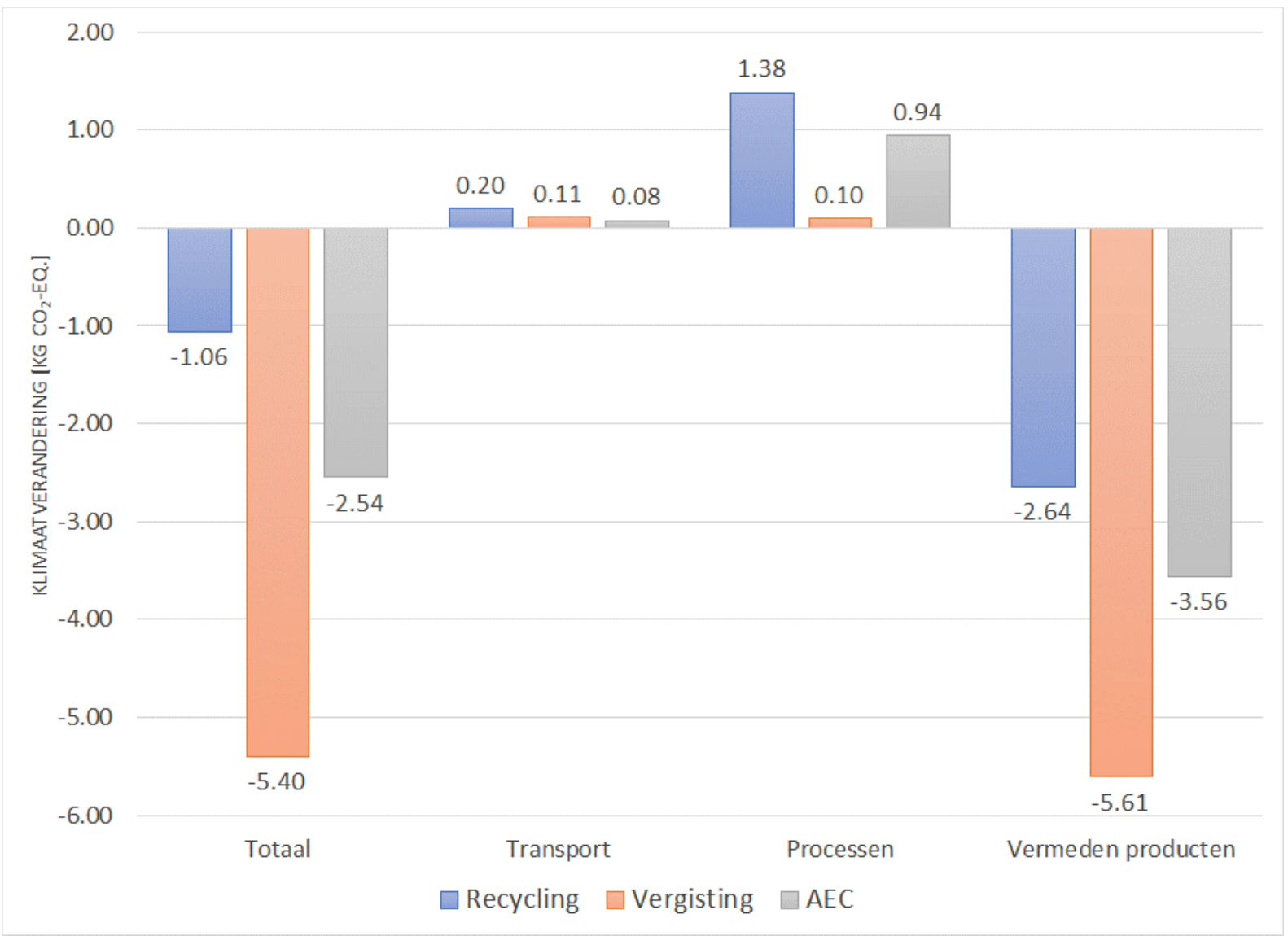

Figuur 8 Vergelijking Carbon footprint van de recyclingroute, de vergistingsroute en de AEC.

\subsection{Gevoeligheidsanalyses}

Bij het uitvoeren van een LCA is het in veel gevallen noodzakelijk om aannames te doen of zijn er andere bronnen van onzekerheid zoals in de nabije toekomst optredende veranderingen binnen het onderzochte systeem. Om het effect hiervan op de uitkomsten van de LCA vast te stellen worden gevoeligheidsanalyses gebruikt. Deze worden hierna gepresenteerd.

Onder de huidige omstandigheden is reeds $89 \%$ van de koffiebekers geschikt voor recycling, het overige deel gaat naar de AEC voor energieterugwinning. Het is mogelijk dat de sorteerefficiency in de toekomst nog verder verhoogd kan worden, bijvoorbeeld door het beter instrueren van de ambtenaren. In een gevoeligheidsanalyse is nagegaan wat het effect zou zijn wanneer $100 \%$ van de bekers geschikt is voor recycling en waardoor ook geen bekers meer voor energieterugwinning worden ingezet. Het resultaat is te zien in Figuur 9. Het milieuvoordeel van de recyclingroute neemt in dat geval met ruim 10 procent toe. 


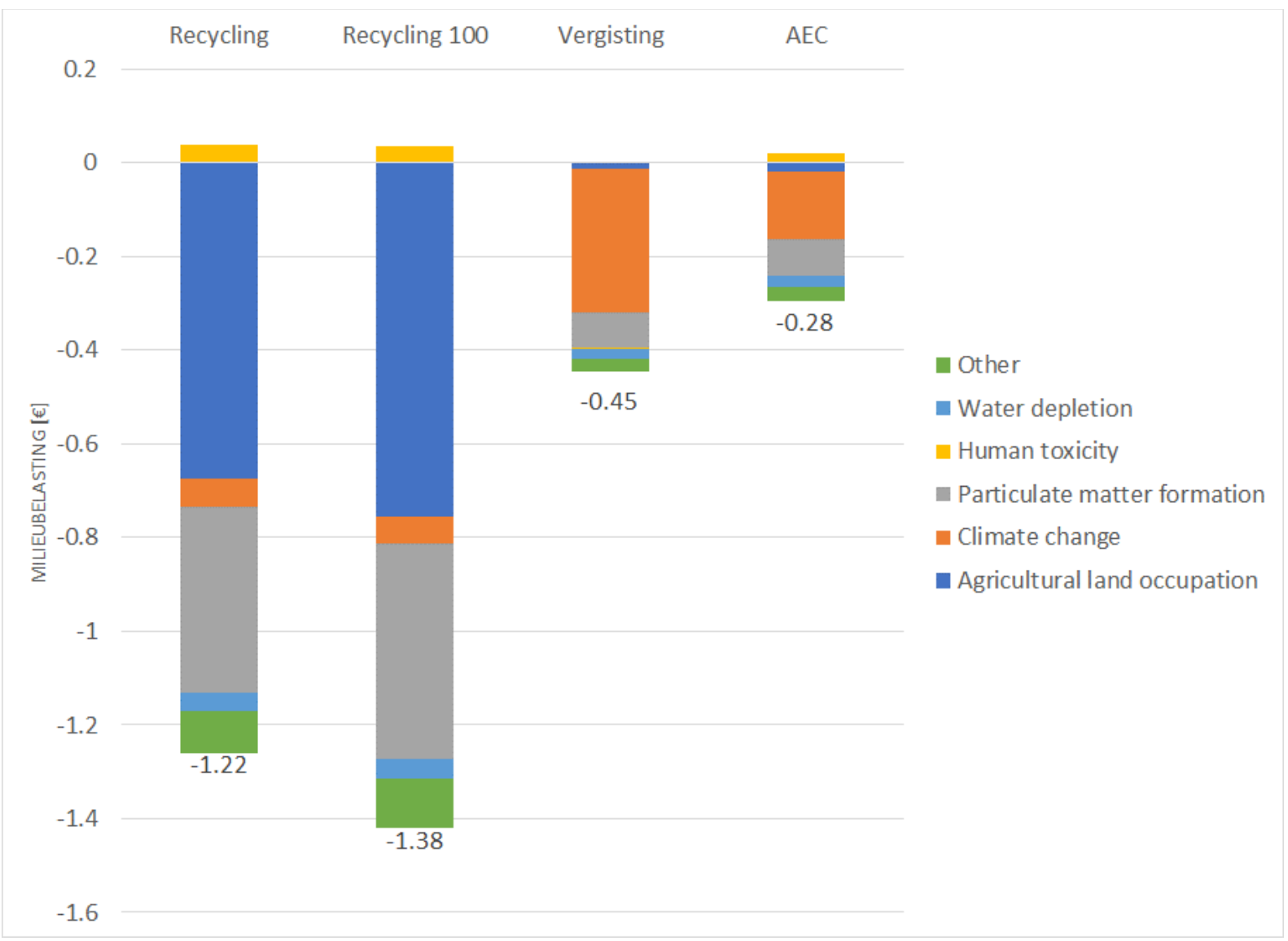

Figuur 9 Gevoeligheidsanalyse voor 100\% sorteerefficiency. 'Recycling 100' geeft het alternatief aan waarbij $100 \%$ van de afgedankte koffiebekers geschikt is voor recycling.

In de huidige studie wordt voor het gebruik van elektriciteit, bijvoorbeeld bij de sortering, de Nederlandse mix genomen. Uitzonderingen zijn het recyclingsproces waarbij een mix van Noorse waterkrachtstroom en zelf opgewekte stroom met PV wordt gebruikt, en het vergistingsproces waar de elektriciteit van de eigen AEC wordt ingezet. Ook in geval van energieterugwinning in de vorm van elektriciteit wordt de Nederlandse mix vermeden. In de Nederlandse elektriciteitsmix maakt stroom afkomstig van kolencentrales $18 \%$ uit. In de toekomst zal dit aandeel verder afnemen ten gunste van elektriciteit uit duurzame bronnen. In een gevoeligheidsanalyse is de Nederlandse elektriciteitsmix aangepast door 50\% van de stroom opgewekt met kolencentrales te vervangen door stroom uit offshore windparken.

De verschuiving van stroom uit kolencentrales naar stroom uit offshore windparken leidt tot een zekere afname van de milieuwinst van de alternatieven, met uitzondering van de recyclingroute waar de afname te verwaarlozen is, zoals in Figuur 10 zichtbaar is. De afname is met 28\% het grootste bij de afvalenergiecentrale. De vergistingsroute is minder gevoelig. 


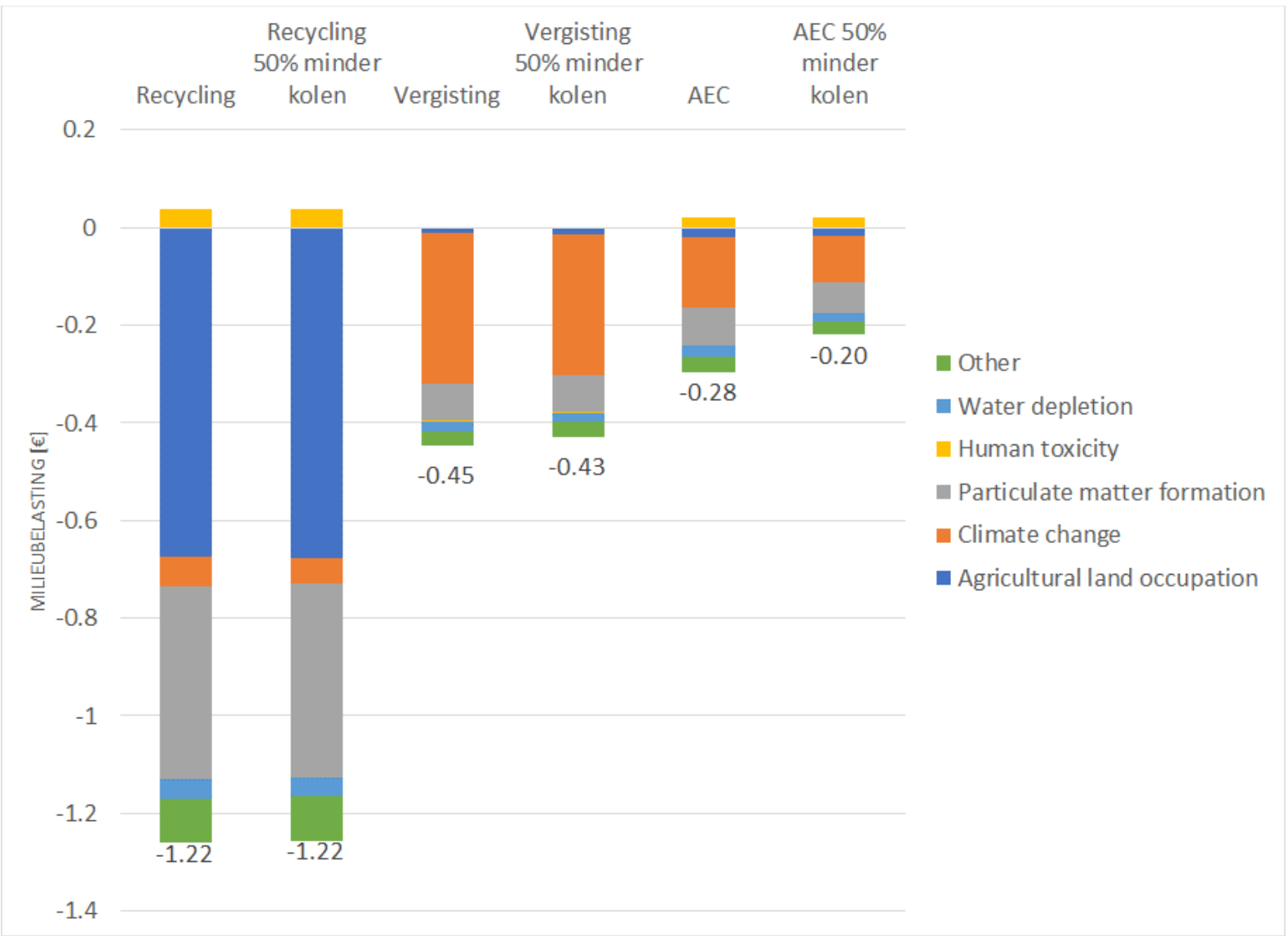

Figuur 10 Gevoeligheidsanalyse voor vervanging van 50\% van de stroom uit kolencentrales door offshore windenergie.

Voor de hoeveelheden vocht en vuil zijn respectievelijk waarden van $10 \%$ en $20 \%$ genomen, gebaseerd op gegevens van een eerdere studie (Ligthart en Ansems, 2004). Het is zeker denkbaar, bijvoorbeeld door invoering van het rookverbod op de werkplek, dat dit percentage omlaag is gegaan. Daarom is in een gevoeligheidsanalyse uitgevoerd voor vocht en vuilpercentages die $50 \%$ lager zijn, dus respectievelijk 5\% en 10\%. Omdat de functionele eenheid gebaseerd is op 1000 schone bekers betekent dit dat de totale massa in het systeem met $12 \%$ afneemt.

Het blijkt, zoals te zien is in Figuur 11, dat met name de vergistingsroute gevoelig is voor het percentage vocht en vuil. De milieuprestatie vermindert daar met $12 \%$ doordat er minder materiaal naar de vergistingsinstallatie gaat en er zo minder biogas wordt geproduceerd. Hierbij moet wel de kanttekening worden gemaakt dat de gasopbrengst (419 $\mathrm{Nm}^{3} /$ ton) van koffiebekers bepaald is voor vuile bekers waarbij geen onderscheid is gemaakt tussen de bijdrage van de koffiebeker zelf en het vocht en vuil. Omdat het vocht en vuil waarschijnlijk een mindere gasopbrengst heeft, is een overschatting van de afname van de milieuprestatie van de vergistingsroute zeer zeker mogelijk. Minder vuil betekent weliswaar minder transport, en daarmee milieubelasting, maar dus ook minder gasopbrengst. De verwachting is dat in werkelijkheid de gasopbrengst met minder dan $12 \%$ zal afnemen omdat de gasopbrengst van het vocht en vuil per massa-eenheid lager zal zijn dan dat van de bekers zelf, hoeveel lager is echter 
niet bekend. Dit zou betekenen dat de gasopbrengst nog steeds afneemt, ook het vocht en vuil draagt bij aan de gasopbrengst, maar met minder dan $12 \%$. De totale milieuprestatie neemt dus af, maar minder dan in deze gevoeligheidsanalyse getoond. De recyclingroute laat een lichte verbetering van de milieuprestatie zien doordat er minder massa hoeft te worden getransporteerd en te worden verwerkt. Er wordt minder onnodige energie gestoken in het pulpen van vuil dat niet bijdraagt aan de productie van papier. Ten slotte laat de AEC ook een verbetering van de milieuprestatie zien. Indien minder vocht en vuil verbrand worden, zijn de emissies per functionele eenheid van 1000 bekers ook kleiner. De bijdrage van vocht en vuil aan de opgewekte energie is relatief gering en het totaal aan vermeden energie wordt dus beperkt beïnvloed.

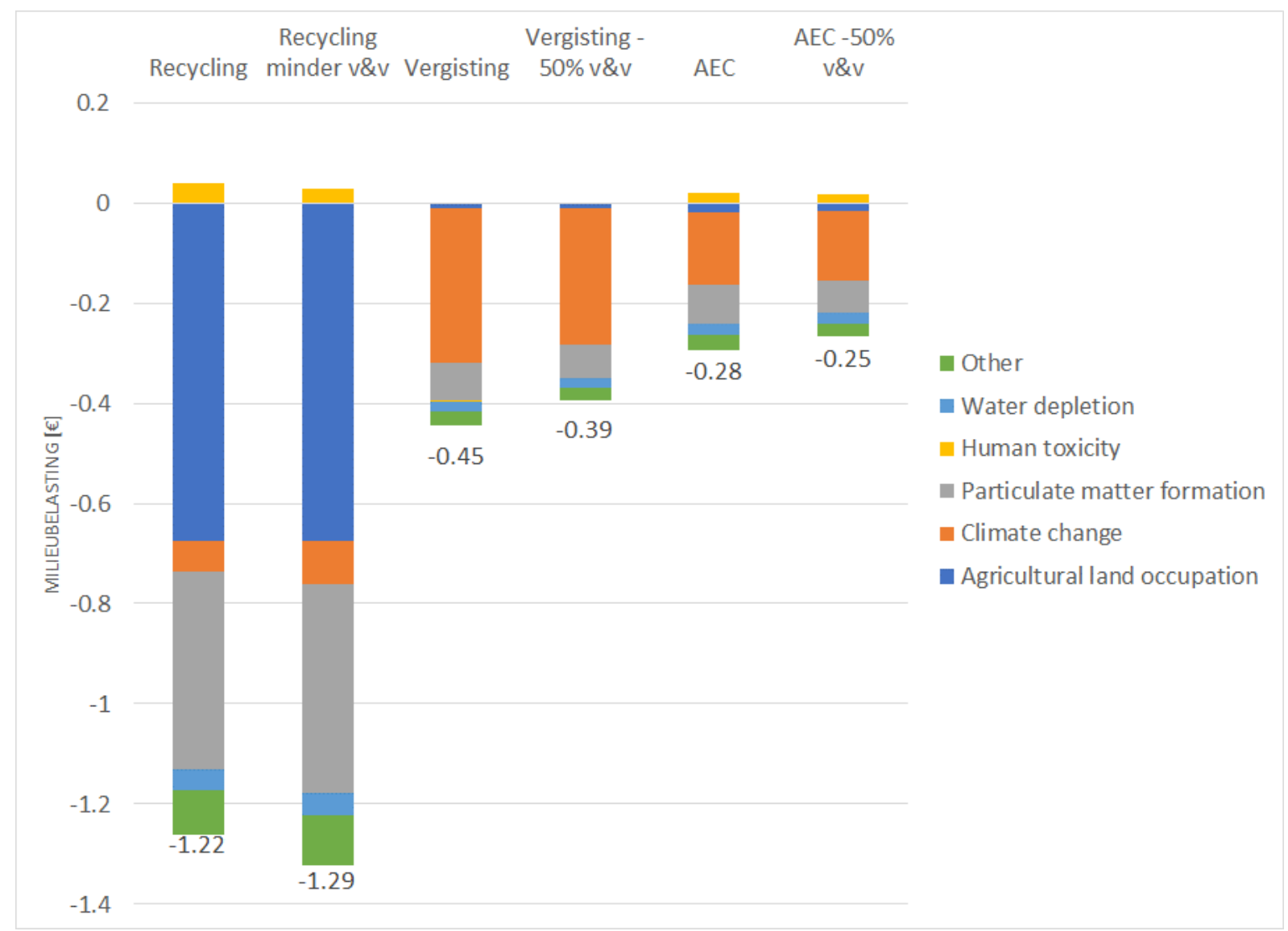

Figuur 11 Gevoeligheidsanalyse voor 50\% minder vocht en vuil. 


\section{$5 \quad$ Potentiële andere verwerkingsroutes in ontwikkeling}

Door middel van gesprekken met experts en literatuuronderzoek is een inventarisatie gemaakt van potentiële andere afvalroutes die momenteel in ontwikkeling zijn, en die naar verwachting de komende $( \pm 3)$ jaren kunnen leiden tot alternatieve opties voor de productie, afvoer en verwerking van koffiebekers. Deze worden in onderstaande paragrafen nader besproken.

\subsection{Karton-PLA versus karton-PE bekers}

Kartonnen koffiebekers bestaan momenteel in een variant gecoat met PLA en een variant gecoat met PE. Dit PE kan in principe ook bio-based PE zijn. Deze beide soorten bekers worden nu door de afvalverwerker niet gescheiden gehouden. Indien het gewenst is dat naast de papiervezels eveneens het plastic wordt gerecycled, dan dienen de karton-PLA bekers gescheiden aangeleverd te worden bij de papier recycler. Vanaf ca 10 ton kan WEPA een batch bekers in principe separaat verwerken. Om de PLA-folie van koffiebekers echter daadwerkelijk apart te kunnen recyclen, dient WEPA een extra zeef- en reinigingsinstallatie in te bouwen. Dit vergt een investering. Tevens dient er rekening mee gehouden te worden dat de kwaliteit van de vezels onder invloed van vocht en micro-organismen achteruit kan gaan tijdens opslag, met name in de zomer. Indien het acceptabel is dat kleine hoeveelheden PLA terecht komen in de PE stroom die hoofdzakelijk van de drankenkartons komt, dan is het eveneens nodig dat WEPA de karton-PLA bekers gescheiden aangeleverd krijgt om te kunnen sturen in het verwerkingsproces.

Karton-PE bekers kunnen samen met drankenkartons gerecycled worden. Aangezien drankenkartons een grote stroom vormen, kunnen karton-PE bekers flexibeler verwerkt worden dan karton-PLA bekers. Echter, hoewel het gebruik van PE versus PLA als coating van de kartonnen koffiebekers niet in dit onderzoek is meegenomen, dient opgemerkt te worden dat de productie van PLA gunstiger scoort op eerder onderzochte milieu-effectcategorieën niethernieuwbaar energiegebruik en broeikasgassen dan PE (Bos, 2011).

\section{$\underline{\text { Conclusie }}$}

Karton-PE koffiebekers kunnen samen met drankenkartons verwerkt worden waardoor deze op dit moment flexibeler gerecycled kunnen worden dan karton-PLA bekers. Hierbij dient opgemerkt dat de productie van PLA gunstiger scoort dan PE op de milieu-effectcategorieën niet-hernieuwbaar energiegebruik en broeikasgassen. Batches karton-PLA vanaf 10 ton kunnen separaat verwerkt worden zodat ook de PLA gerecycled kan worden. Hiervoor is het nodig dat de karton-PLA koffiebekers gescheiden worden aangeleverd. Tevens dient een extra zeef- en reinigingsinstallatie ingebouwd te worden.

\subsection{Bio-based plastic koffiebekers}

Koffiebekers kunnen eveneens gemaakt worden van bio-based hittestabiel PLA. Total Corbion claimt voor dit product een lagere $\mathrm{CO}_{2}$ voetafdruk in vergelijking met PS bekers en gecoate kartonnen koffiebekers (Total Corbion, 2017). Het is niet duidelijk hoe deze hittestabiele PLA 
koffiebeker scoort op andere milieueffecten dan de $\mathrm{CO}_{2}$ voetafdruk. $\mathrm{Na}$ brongescheiden inzameling kunnen dergelijke bekers gerecycled worden tot recyclaat, bijvoorbeeld bij Loopla (2017).

\section{Conclusie}

Total Corbion claimt voor hittestabiele PLA koffiebekers een lagere $\mathrm{CO}_{2}$ voetafdruk dan gecoate kartonnen koffiebekers; de totale milieuimpact van deze bekers is niet duidelijk.

\subsection{Biovezel versterkte/gevulde composieten}

De cellulosevezels uit karton-PLA koffiebekers zijn in principe te gebruiken als versterkende/vullende vezels in composieten.

\section{Technologie}

In een extruder wordt een plastic (thermoplast) zoals bijvoorbeeld PP, PE of PLA opgesmolten en gemengd met biovezels (Figuur 12), ook wel 'compounderen' genoemd. Het resultaat is een materiaal (ook wel 'compound' genoemd) dat in korrelvorm (ook wel 'granulaat' genaamd) wordt gemaakt. Dit granulaat wordt in een spuitgietmachine opnieuw gesmolten en in een matrijs gespoten tot een gewenste vorm (Figuur 13). Indien correct verwerkt kunnen biovezels de plastics beter maken wat betreft:

- Sterkte: Minder materiaal nodig om aan sterkte-eisen te voldoen

- Stijfheid (minder doorbuigen bij een bepaalde belasting): Dunnere en goedkopere producten mogelijk

- Weerstand tegen vervormen bij hogere temperatuur: Gewenst/vereist voor veel toepassingen in auto's en apparaten

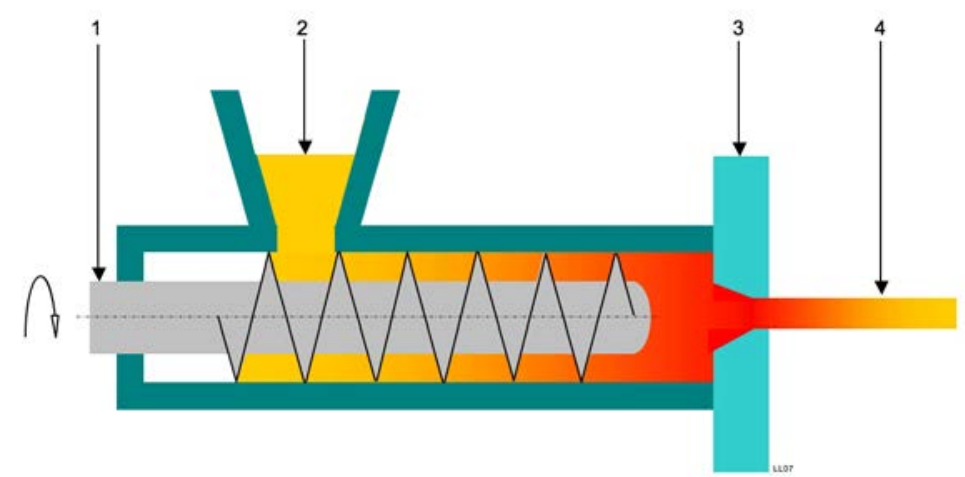

Figuur 12. Schematische weergave van extrusieproces voor mengen van biovezels in plastics: $1=$ Extruder, 2 = Thermoplastisch granulaat en biovezels, $3=$ Granulator, $4=$ Korrels van gemengd plastic en biovezels (Extruderen, 2014). 


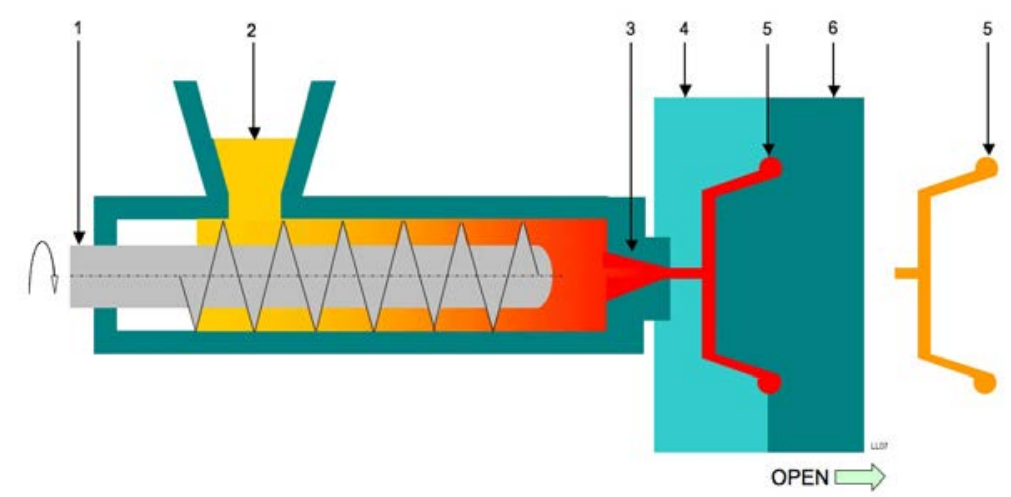

Figuur 13. Spuitgiet proces. $1=$ Doseerschroef, $2=$ Granulaat, $3=$ Inspuitopening (spuitmond), $4=$ Matrijs-helft 1, 5 = Product, $6=$ Matrijs-helft 2 (Spuitgieten, 2017).

De biovezels dienen voor verwerking in plastics min of meer droog te zijn. Papiersnippers geven matige compound-eigenschappen.

\section{$\underline{\text { Status }}$}

De technologie is min of meer uitontwikkeld. In dergelijke composieten worden met name biovezels als houtvezels, vlas en andere vezels toegepast. Spuitgietbare composieten zijn sinds 1015 jaren in kleine volumes op de markt. In 2012 was het volume voor spuitgietbare composieten in de EU ca 17 kton (Nova, 2015). De markt is nog klein doordat enerzijds biovezelprijzen relatief hoog zijn t.o.v. goedkope (minerale) vullers zoals krijt en talk, en anderzijds relatief minder presteren dan (duurdere) glasvezels. Desalniettemin presenteert Nova in dezelfde studie de verwachting dat in 2020 het marktvolume voor spuitgietbare composieten vervijfvoudigt t.o.v. 2012.

Een aantal bedrijven waaronder Sappi in Maastricht hebben spuitgietbare composieten (compounds) op basis van papiervezel ontwikkeld. Sappi gebruikt de papiervezels om witte en min of meer geurloze compounds te maken, iets dat met de reguliere houtvezels, vlas of andere biovezels moeilijker is. Het gebruikelijke extractieproces van cellulosevezels uit hout voor de productie van papier heeft echter een ongunstig effect voor optimaal gebruik in compounds: de vezels dienen in papier in zekere zin intern beschadigd te zijn, voor toepassing in compounds is dat ongewenst.

\section{$\underline{\text { Conclusie }}$}

Gerecyclede papiervezels hebben meer waarde voor de productie van nieuw papier dan voor composieten. De verwachting is dat dit de komende jaren niet verandert.

\subsection{Vergisting en recycling}

Voor de nu onderzochte verwerkingsroutes recycling en vergisting worden de komende 3 jaren geen significante verbeteringen in de technologieën verwacht. 


\section{Conclusies en aanbevelingen}

\subsection{Levenscyclusanalyse}

Wanneer de milieuprestatie van de recyclingroute en die van de vergistingsroute voor de verwerking van warmedrankenbekers met een coating van PLA, op basis van de ReCiPe midpoints methode, gecombineerd met schaduwkosten, worden beoordeeld, presteert de recyclingroute duidelijk het beste. Het recyclen van de afgedankte bekers vermijdt de inzet van primaire papierpulp. Hiermee wordt het sulfaatpulpproces vermeden, en dat leidt onder meer tot minder uitstoot van fijnstof, een belangrijk milieueffect van dit proces. Doordat de productie van hout in productiebossen wordt vermeden is er sprake van minder agrarisch landgebruik. De energieterugwinning in de afvalenergiecentrale (AEC) vermijdt de opwekking van elektriciteit en warmte met fossiele brandstoffen; dit leidt tot winst op het gebied van klimaatverandering (reductie $\mathrm{CO}_{2}$ uitstoot). Verwerking van de bekers in de AEC levert door energieterugwinning ook een milieuwinst op, maar deze is kleiner dan die van de twee alternatieve routes.

Momenteel gaat reeds $89 \%$ van de afgedankte bekers naar de recycling, de rest is te vervuild. De recyclingroute zou nog beter presteren, wanneer dit percentage verder omhoog gaat. Door minder vocht en vuil in de afgedankte bekers te laten zitten, kunnen er meer bekers richting recycling, en wordt er zo meer primaire pulp vermeden. Dit levert een grotere milieuwinst op.

Ook de vergistingsroute levert milieuwinst op, met name door het opwekken van elektriciteit en warmte in een WKK-installatie. Daarnaast leidt de inzet van groen gas in het aardgasnet tot een reductie van de emissie van fossiel koolstofdioxide doordat minder (fossiel) aardgas wordt verbrand. De productie van compost uit het digestaat van de vergiste bekers draagt mede bij aan de milieuprestatie door het vervangen van veen in potgrond en door het vermijden van de emissies, van fossiel $\mathrm{CO}_{2}$, bij het gebruik van veen.

Vergelijking van de beide verwerkingsroutes op basis van de Carbon footprint laat de vergistingsroute als beste alternatief voor de verwerking van afgedankte koffiebekers zien. Per 1000 bekers wordt 5,4 $\mathrm{kg} \mathrm{CO} 2$ vermeden. De vermeden productie van warmte en elektriciteit met de WKK, maar ook de inzet van groen gas in het Nederlandse aardgasnet, leveren de grootste bijdragen aan het reduceren van broeikasgassen. Verwerking in de AEC neemt een intermediaire positie in met een hoeveelheid vermeden $\mathrm{CO}_{2}$ van 2,54 kg.

Het verschil in rangorde van de verwerkingsroutes bij de milieuprestatie op basis van schaduwkosten of op basis van de Carbon footprint is gelegen in het feit dat bij de recyclingroute klimaatverandering slechts 5\% bijdraagt en bij de vergistingsroute $69 \%$. Bij beschouwing van de Carbon footprint wordt voor de recyclingroute een veel groter deel van de totale milieubelasting buiten beschouwing gelaten, vergeleken met de vergistingsroute. 
De vergelijking van de verwerkingsroutes vergisting en recycling is gebaseerd op locatiespecifieke gegevens van de twee routes. De recycling van warmedrankenbekers zou in de toekomst in principe ook op andere locaties kunnen plaatsvinden. De milieubelasting van het proces zelf zou dan kunnen wijzigen, bijvoorbeeld door een andere samenstelling van de gebruikte elektriciteit. De vergisting van koffiebekers kan nu al op andere locaties worden uitgevoerd; de bijdrage van de milieubelasting van het proces zelf aan de totale milieubalans zal naar alle waarschijnlijkheid niet veel anders zijn dan voor de huidige locatie. De transportafstand heeft een beperkte invloed op zowel milieubelasting als klimaatverandering. De verhouding tussen de afzet van compost als potgrond of in de landbouw is wel van belang; de grootste milieuwinst wordt behaald door afzet als potgrond. In de huidige studie wordt $90 \%$ van de compost als zodanig afgezet, een lager percentage zal tot een afname van de milieuwinst leiden.

Er wordt aanbevolen dat de Rijksdienst voor Ondernemend Nederland, op basis van de resultaten van de voorliggende milieuanalyse, kiest voor de recycling van afgedankte warme drankenbekers. Wanneer de kwaliteit van het aangeleverde materiaal nog verder verbeterd kan worden, kunnen door de sorteerder Destra meer bekers voor recycling worden aangeboden en levert de recyclingroute nog meer milieuvoordeel op.

\subsection{Alternatieve verwerkingsroutes}

Karton-PE koffiebekers kunnen samen met drankenkartons verwerkt worden waardoor deze veel flexibeler gerecycled kunnen worden dan karton-PLA bekers. Batches karton-PLA vanaf 10 ton kunnen separaat verwerkt worden zodat ook de PLA gerecycled kan worden. Hiervoor is het nodig dat de karton-PLA koffiebekers gescheiden worden aangeleverd. Tevens dient een extra zeef- en reinigingsinstallatie ingebouwd te worden.

Voor hittestabiele PLA koffiebekers claimt Total Corbion een lagere $\mathrm{CO}_{2}$ voetafdruk dan gecoate kartonnen koffiebekers; de totale milieu-impact van deze bekers is niet duidelijk.

Tevens zijn er de afgelopen 10 jaar technologieën voor toepassing van papier in composieten ontwikkeld. Gerecyclede papiervezels hebben echter meer waarde voor de productie van nieuw papier dan voor composieten. Deze verschillende composiettechnologieën zullen daarom naar verwachting de komende jaren niet leiden tot concurrenten voor de nu onderzochte verwerkingsroutes.

De komende $( \pm 3)$ jaren zijn voor gecoate kartonnen koffiebekers geen andere verwerkingsroutes op industriële schaal te verwachten dan de nu toegepaste/onderzochte: vergisten tot biogas en recyclen tot papier, naast verbranden in een AEC. Eveneens worden geen significante verbeteringen in de technologieën verwacht. 


\section{Literatuur}

- Bos, H., Conijn, S., Corré, W., Meesters, K., Patel, M., 2011. Duurzaamheid van biobased producten - Energiegebruik en broeikasgasemmissie van producten met suikers als grondstof, Wageningen Food \& Biobased Research, ISBN 978-90-8585-902-4, http://www.groenegrondstoffen.nl/downloads/Boekjes/11Duurzaamheidvan\%20biobas ed $\% 20$ producten.pdf

- De Bruyn, S., Ahdour, S., Bijleveld, M., de Graff, L., Schroten, A., \& Vergeer, R. (2017). Handboek. Milieuprijzen 2017 Methodische onderbouwing van kengetallen gebruikt voor waardering van emissies en milieu-impacts. Delft.

- De Meester S, Ragaert K, 2017. Predictive model for the Dutch post-consumer plastic packaging recycling system and implications for the circular economy, Waste Management (in press), https://doi.org/10.1016/j.wasman.2017.10.034

- Extruderen, 2014. https://nl.wikipedia.org/wiki/Extruderen, bezocht op 6 oktober 2017.

- Goedkoop, M., Huijbregts, M., Schryver, A. De, Struijs, J., van Zelm, R., \& Zelm, R. van. (2013). ReCiPe 2008. A life cycle impact assessment method which comprises harmonised category indicators at the midpoint and the endpoint level (1st ed. (r). The Hague: Ministry of Housing, Spatial Planning and Environment (VROM).

- Harmelen, A. K. Van, Korenromp, R. H. J., Deutekom, C. Van, \& Ligthart, T. N. (2006). The price of toxicity. Methodology for the assessment of shadow prices for human toxicity , ecotoxicity and abiotic depletion. In Quantified Eco-Efficiency (Vol. 2, pp. 105125). Springer International Publishing.

- ISO. (2006a). Environmental management - Life cycle assessment - Principles and framework (ISO 14040:2006). Brussels: CEN (EUROPEAN COMMITTEE FOR STANDARDIZATION).

- ISO. (2006b). Environmental management - Life cycle assessment - Requirements and guidelines (ISO 14044:2006). Brussels: CEN (EUROPEAN COMMITTEE FOR STANDARDIZATION).

- Ligthart, T.N. en Ansems, A.M.M. (2004) Eco-efficiency van retoursystemen van gebruikte eenmalige PS koffiebekers. Rapportnr TNO R 2003/453

- Loopla, 2017. http://www.loopla.org/, bezocht op 11 december 2017.

- Manders J (WEPA), 2017. Persoonlijke communicatie.

- Nova, 2015. WPC/NFC Market Study 2014-10 (Update 2015-06), https://compositesuk.co.uk/system/files/documents/WPC-NFC-Market-Study-ShortVerson\%202015.pdf , bezocht op 6 oktober 2017.

- OPure B.V. (2017). Analysebericht: Onderzoek vergistbaarheid 017/RMO/015/CO/G. Ede.

- Pelican Rouge, 2017. Re-use - Koffiebeker Recycle Totaalconcept, product flyer verkregen van RVO. 
- Rijkswaterstaat, 2017. Afvalverwerking in Nederland, gegevens 2016. Utrecht, The Netherlands. https://www.afvalcirculair.nl/onderwerpen/helpdeskafvalbeheer/publicaties/downloads/afvalverwerking-7/.

- Spuitgieten, 2017. https://nl.wikipedia.org/wiki/Spuitgieten , bezocht op 6 oktober 2017.

- Total Corbion, 2017. Persbericht, http://www.biobasedeconomy.nl/wpcontent/uploads/2017/05/Total-Corbion-PLA-to-showcase-innovative-biobasedpackaging-at-Interpack-170502.pdf , bezocht op 11 december 2017. 


\section{Lijst van afkortingen}

\begin{tabular}{|l|l|}
\hline Afkorting & Betekenis \\
\hline AEC & Afvalenergiecentrale \\
\hline CFC & Chlorofluorocarbons \\
\hline FTE & Full time equivalents \\
\hline ISO & International Standard Organization \\
\hline LCA & Levenscyclusanalyse \\
\hline MJ & Megajoule \\
\hline NIR & Nabij-infrarood \\
\hline Nm & Normaal kubieke meter \\
\hline NMVOC & Non-methane Volatile Organic Compounds \\
\hline PE & Polyethyleen \\
\hline PET & Polyethyleentereftalaat \\
\hline PLA & Polylactic acid (polymelkzuur) \\
\hline PP & Polypropyleen \\
\hline PS & Polystyreen \\
\hline RDF & Refuse derived fuel \\
\hline RVO & Rijksdienst voor Ondernemend Nederland \\
\hline
\end{tabular}




\section{Bijlage A LCA netwerken}

In deze bijlage wordt de milieuanalyse als netwerk van een verwerkingssysteem getoond. 


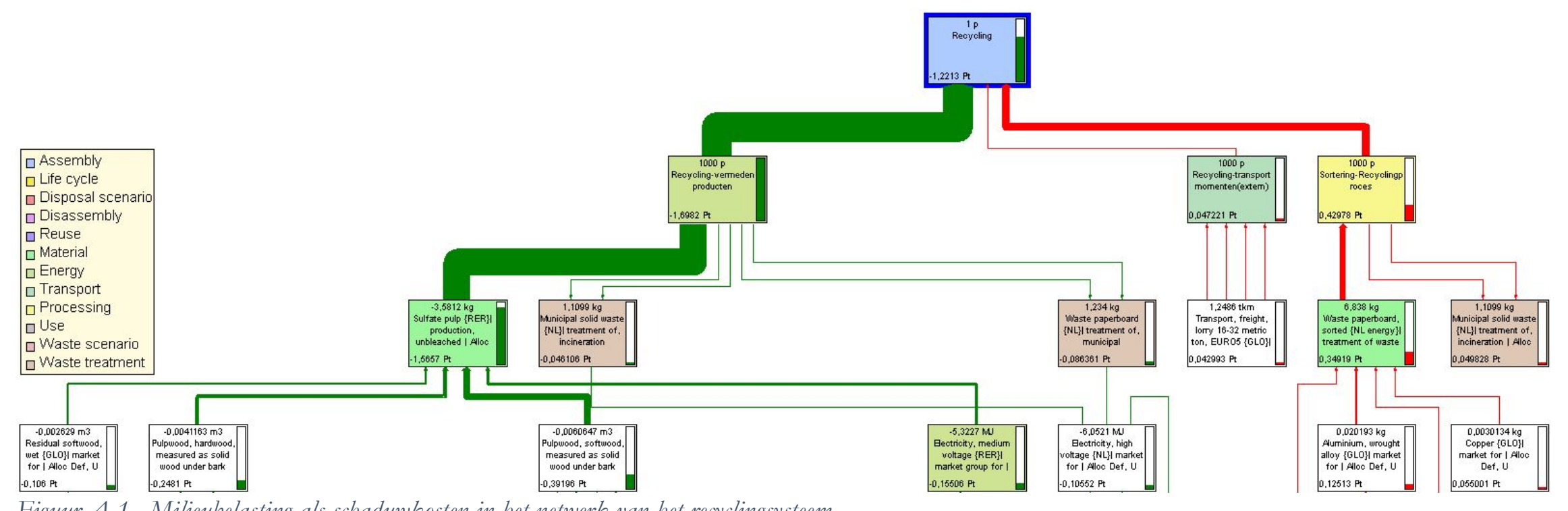




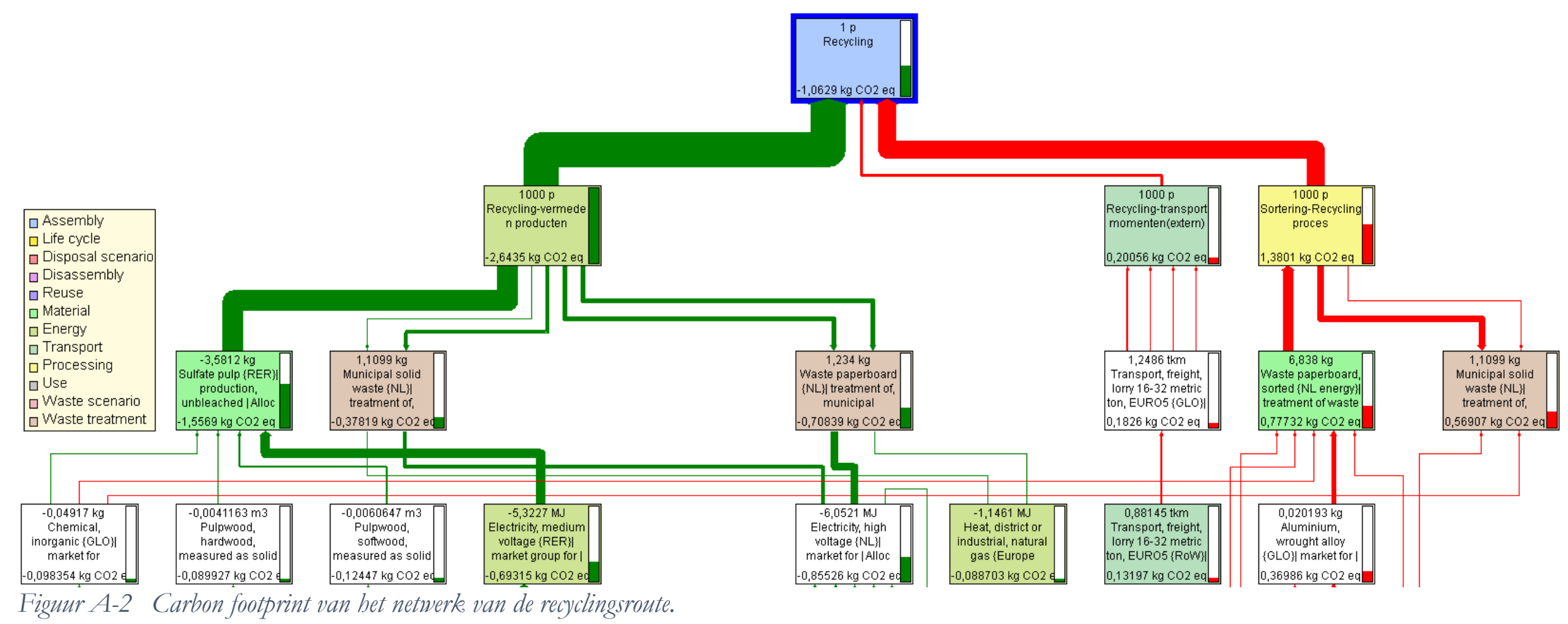




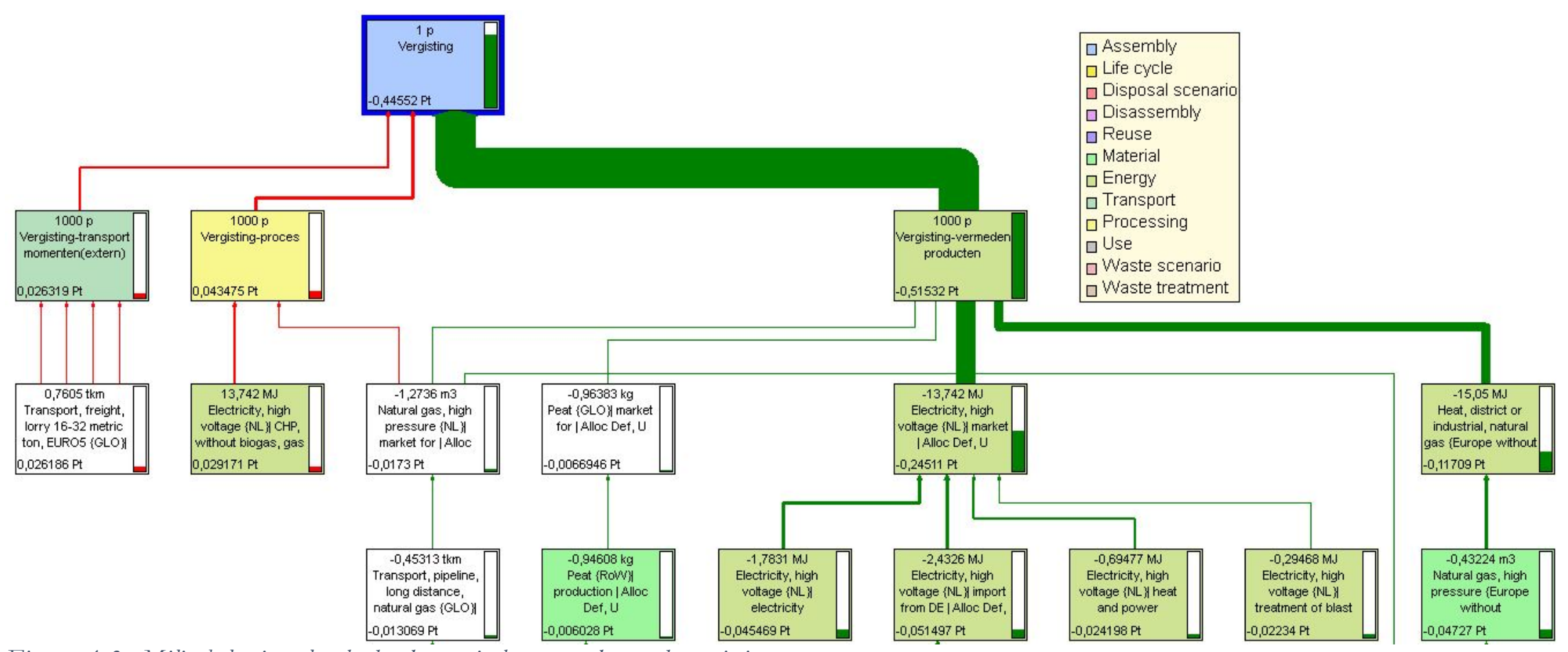

Figur A-3 Milieubelasting als schaduwkeosten in het netwerk van de vergistingsroute. 


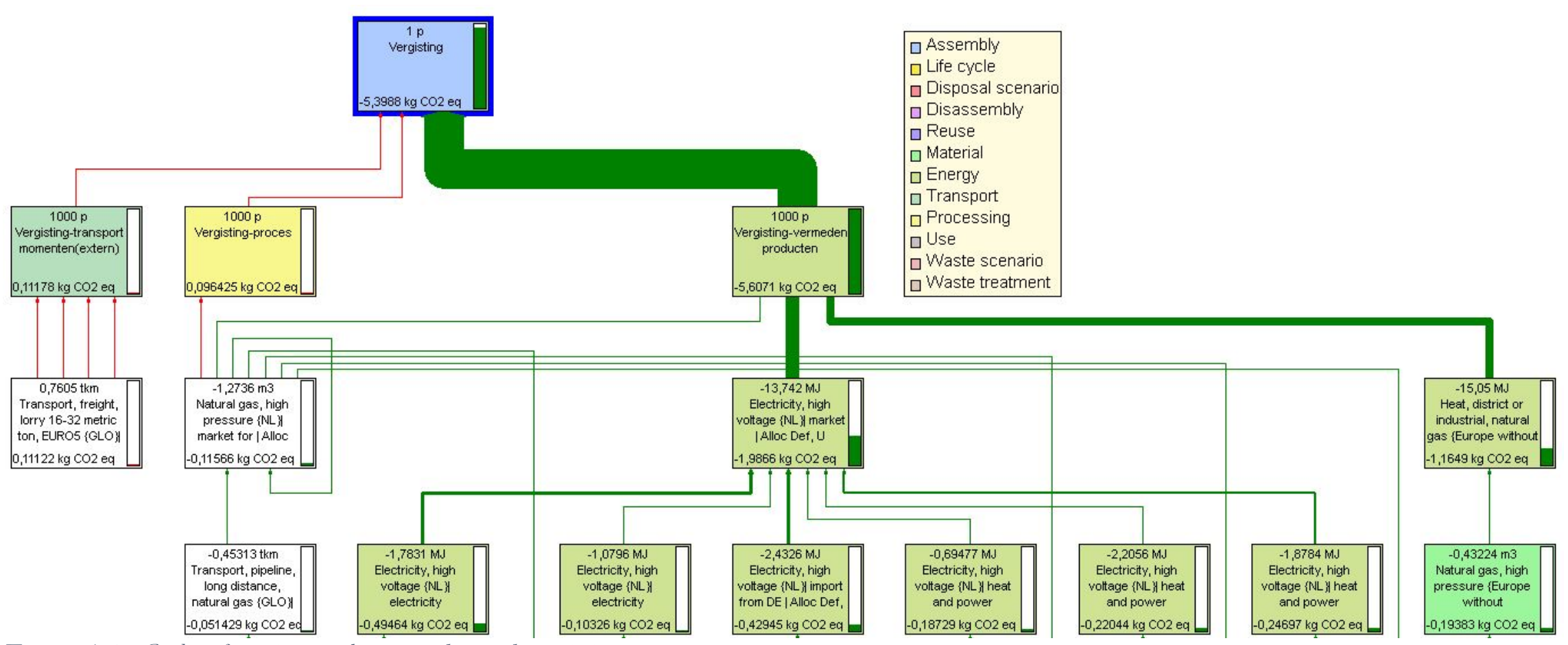

Figur A4 Carbon footprint van het netwerk van de vergistingsroute. 


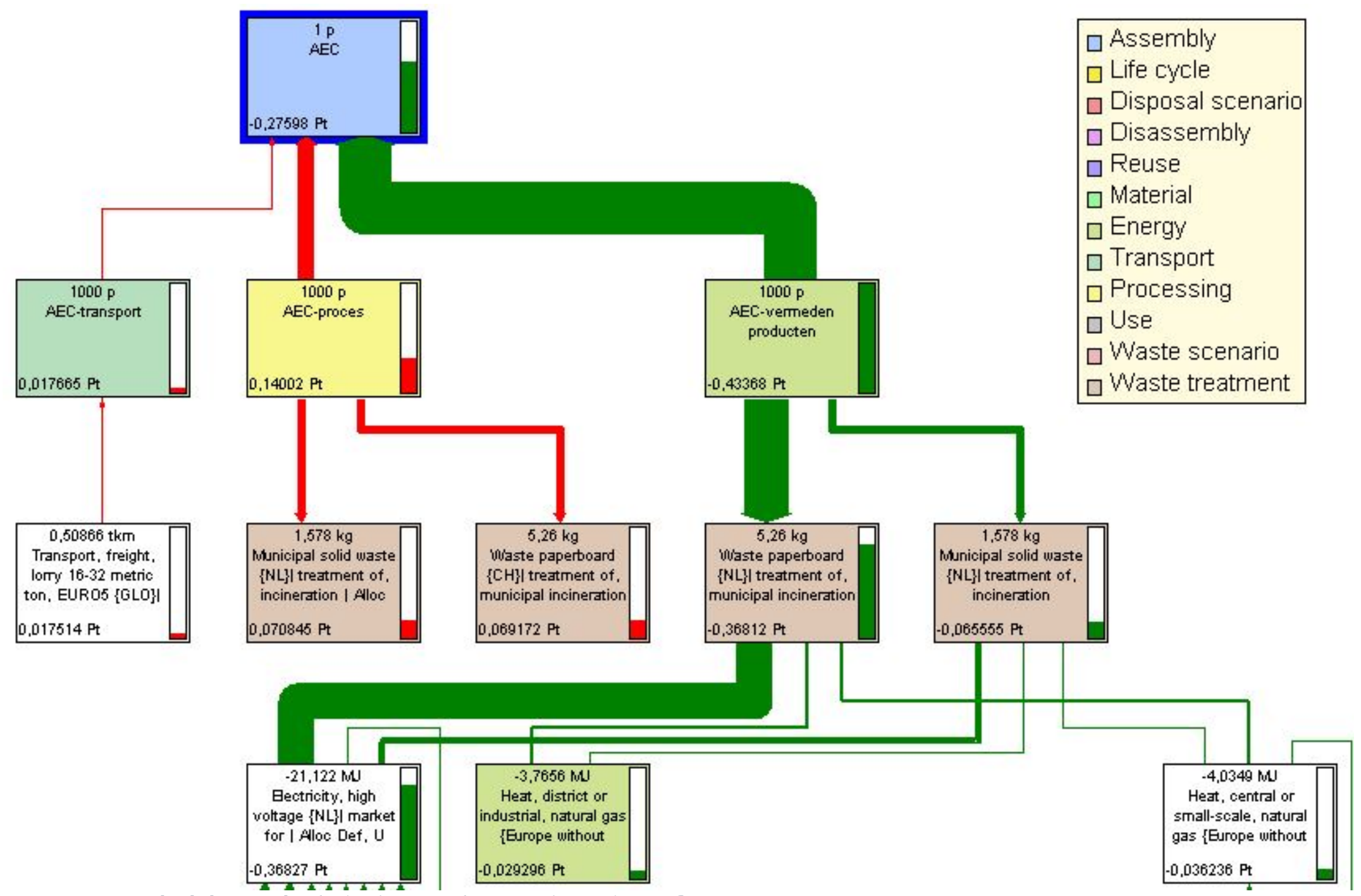

Figuur A-5 Milieubelasting als schaduwkosten in het netwerk van de AEC. 


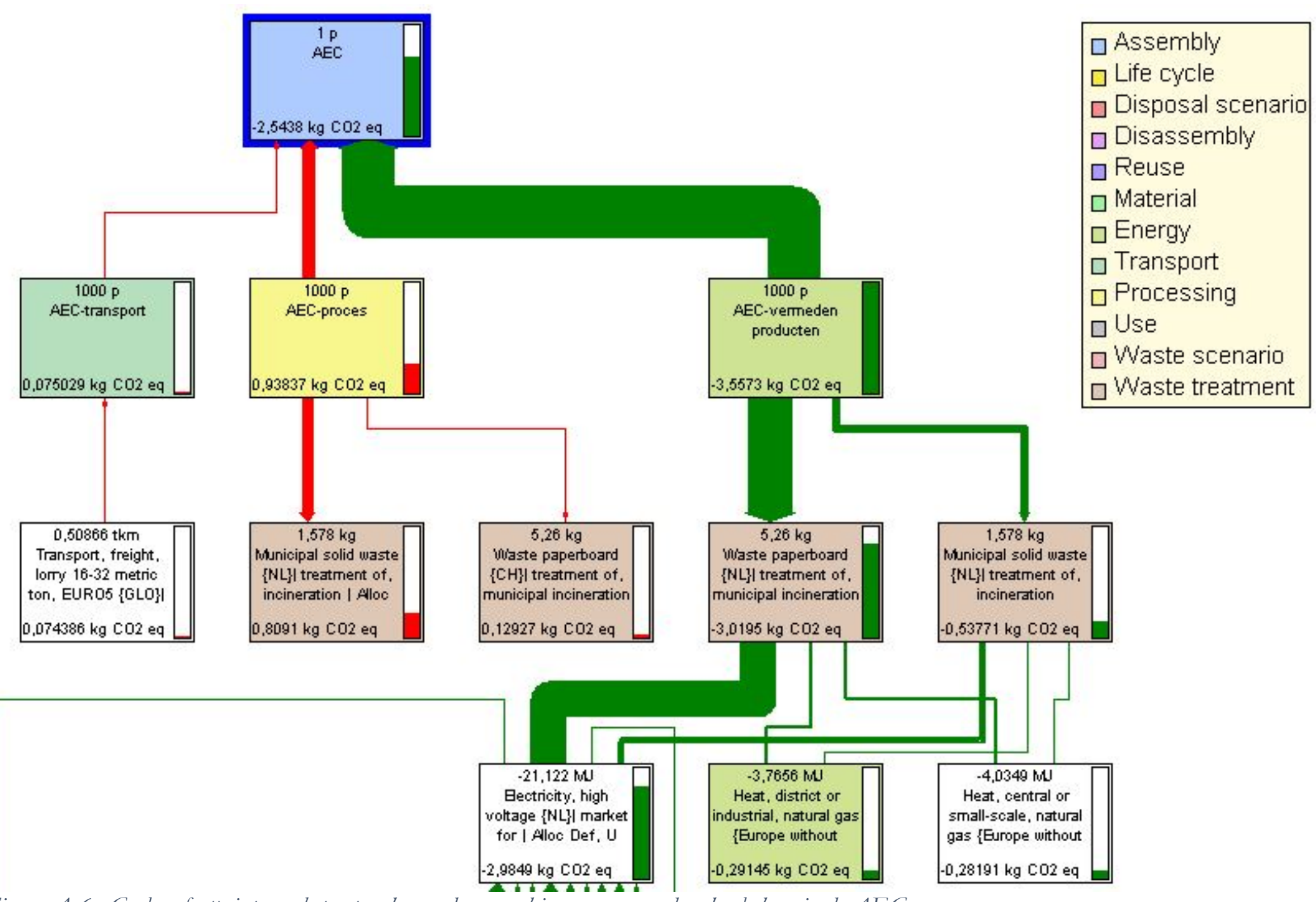

Figuur A-6 Carbon footprint van het netwerk, van de verwerking van warmedrankenbekers in de AEC. 


\section{Bijlage B Gekarakteriseerde resultaten verwerkingsroutes}

In deze bijlage worden de gekarakteriseerde milieuprofielen, dus zonder toepassing van schaduwprijzen, van de verwerkingssystemen getoond.

Tabel B-1 Milieuprofiel van de recycling van 1000 warmedrankenbekers.

\begin{tabular}{|c|c|c|c|c|c|}
\hline Impact category & Unit & 蓫 & 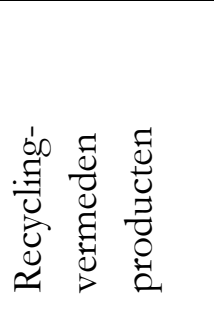 & 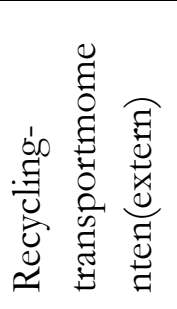 & 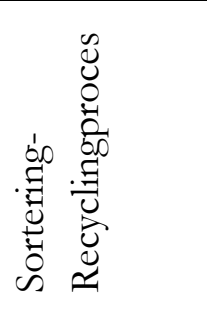 \\
\hline Climate change & $\mathrm{kg} \mathrm{CO} 2 \mathrm{eq}$ & $-1.06 \mathrm{E}+00$ & $-2.64 \mathrm{E}+00$ & 2.01E-01 & $1.38 \mathrm{E}+00$ \\
\hline Ozone depletion & $\mathrm{kg}$ CFC-11 eq & $-2.15 \mathrm{E}-07$ & $-3.24 \mathrm{E}-07$ & 3.83E-08 & 7.07E-08 \\
\hline $\begin{array}{l}\text { Terrestrial } \\
\text { acidification }\end{array}$ & kg SO2 eq & $-6.85 \mathrm{E}-03$ & $-1.43 \mathrm{E}-02$ & $5.76 \mathrm{E}-04$ & $6.90 \mathrm{E}-03$ \\
\hline $\begin{array}{l}\text { Freshwater } \\
\text { eutrophication }\end{array}$ & kg P eq & $5.06 \mathrm{E}-06$ & $-1.88 \mathrm{E}-04$ & $5.41 \mathrm{E}-07$ & $1.92 \mathrm{E}-04$ \\
\hline $\begin{array}{l}\text { Marine } \\
\text { eutrophication }\end{array}$ & $\mathrm{kg} \mathrm{N}$ eq & $-6.00 \mathrm{E}-04$ & $-1.21 \mathrm{E}-03$ & $2.50 \mathrm{E}-05$ & $5.86 \mathrm{E}-04$ \\
\hline Human toxicity & $\mathrm{kg} 1,4-\mathrm{DB}$ eq & $2.50 \mathrm{E}-01$ & $-1.33 \mathrm{E}-01$ & 4.05E-02 & 3.43E-01 \\
\hline $\begin{array}{l}\text { Photochemical } \\
\text { oxidant formation }\end{array}$ & kg NMVOC & $-7.30 \mathrm{E}-03$ & $-1.15 \mathrm{E}-02$ & 7.55E-04 & $3.49 \mathrm{E}-03$ \\
\hline $\begin{array}{l}\text { Particulate matter } \\
\text { formation }\end{array}$ & kg PM10 eq & $-5.73 \mathrm{E}-03$ & $-8.91 \mathrm{E}-03$ & $3.03 \mathrm{E}-04$ & $2.88 \mathrm{E}-03$ \\
\hline $\begin{array}{l}\text { Terrestrial } \\
\text { ecotoxicity }\end{array}$ & kg 1,4-DB eq & $-7.45 \mathrm{E}-05$ & $-4.32 \mathrm{E}-04$ & $9.57 \mathrm{E}-05$ & $2.62 \mathrm{E}-04$ \\
\hline $\begin{array}{l}\text { Freshwater } \\
\text { ecotoxicity }\end{array}$ & kg 1,4-DB eq & 4.66E-03 & $-1.17 \mathrm{E}-03$ & $1.31 \mathrm{E}-04$ & $5.70 \mathrm{E}-03$ \\
\hline Marine ecotoxicity & $\mathrm{kg} 1,4-\mathrm{DB}$ eq & $2.98 \mathrm{E}-03$ & $-2.18 \mathrm{E}-03$ & 7.31E-04 & 4.42E-03 \\
\hline Ionising radiation & $\mathrm{kBq} U 235 \mathrm{eq}$ & $-1.52 \mathrm{E}-01$ & $-1.92 \mathrm{E}-01$ & $1.33 \mathrm{E}-02$ & $2.66 \mathrm{E}-02$ \\
\hline $\begin{array}{l}\text { Agricultural land } \\
\text { occupation }\end{array}$ & $\mathrm{m} 2 \mathrm{a}$ & $-1.82 \mathrm{E}+01$ & $-1.83 \mathrm{E}+01$ & $1.00 \mathrm{E}-03$ & $7.35 \mathrm{E}-02$ \\
\hline $\begin{array}{l}\text { Urban land } \\
\text { occupation }\end{array}$ & $\mathrm{m} 2 \mathrm{a}$ & $-2.35 \mathrm{E}-01$ & $-2.88 \mathrm{E}-01$ & 8.07E-03 & $4.50 \mathrm{E}-02$ \\
\hline $\begin{array}{l}\text { Natural land } \\
\text { transformation }\end{array}$ & $\mathrm{m} 2$ & $-1.49 \mathrm{E}-03$ & $-1.55 \mathrm{E}-03$ & $4.89 \mathrm{E}-06$ & $5.53 \mathrm{E}-05$ \\
\hline Water depletion & $\mathrm{m} 3$ & $-4.58 \mathrm{E}-02$ & $-7.36 \mathrm{E}-02$ & $3.45 \mathrm{E}-04$ & $2.74 \mathrm{E}-02$ \\
\hline Metal depletion & $\mathrm{kg} \mathrm{Fe} \mathrm{eq}$ & 3.84E-01 & $-3.99 \mathrm{E}-02$ & $6.58 \mathrm{E}-04$ & 4.23E-01 \\
\hline Fossil depletion & kg oil eq & $-5.98 \mathrm{E}-01$ & $-8.74 \mathrm{E}-01$ & $7.20 \mathrm{E}-02$ & $2.04 \mathrm{E}-01$ \\
\hline
\end{tabular}


Tabel B-2 Milieuprofiel van de vergisting van 1000 warmedrankenbekers.

\begin{tabular}{|c|c|c|c|c|c|}
\hline 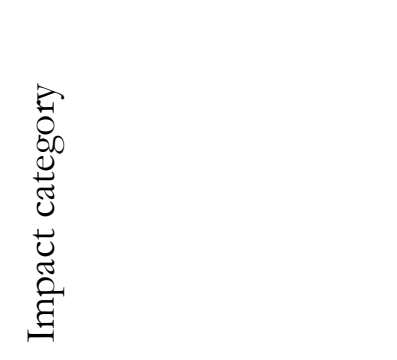 & 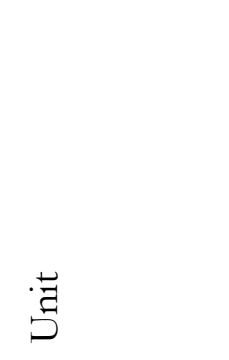 & $\begin{array}{l}\text { తేँ } \\
\stackrel{0}{0}\end{array}$ & 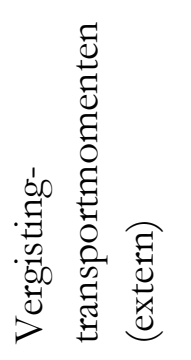 & 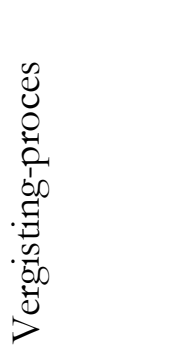 & 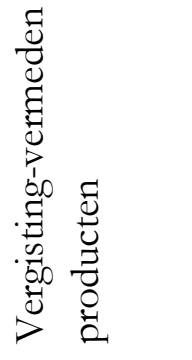 \\
\hline Climate change & $\mathrm{kg} \mathrm{CO} 2 \mathrm{eq}$ & $-5.40 \mathrm{E}+00$ & $1.12 \mathrm{E}-01$ & $9.64 \mathrm{E}-02$ & $-5.61 E+00$ \\
\hline Ozone depletion & $\mathrm{kg}$ CFC-11 eq & $-3.77 \mathrm{E}-07$ & $2.14 \mathrm{E}-08$ & $8.49 \mathrm{E}-09$ & $-4.06 \mathrm{E}-07$ \\
\hline Terrestrial acidification & $\mathrm{kg} \mathrm{SO} 2 \mathrm{eq}$ & $-2.27 \mathrm{E}-03$ & $3.21 \mathrm{E}-04$ & $1.30 \mathrm{E}-03$ & $-3.89 \mathrm{E}-03$ \\
\hline $\begin{array}{l}\text { Freshwater } \\
\text { eutrophication }\end{array}$ & $\mathrm{kg} P$ eq & $-8.76 \mathrm{E}-05$ & $3.02 \mathrm{E}-07$ & $3.68 \mathrm{E}-06$ & $-9.16 \mathrm{E}-05$ \\
\hline Marine eutrophication & $\mathrm{kg} \mathrm{N}$ eq & $-9.94 \mathrm{E}-05$ & $1.39 \mathrm{E}-05$ & $2.56 \mathrm{E}-05$ & $-1.39 \mathrm{E}-04$ \\
\hline Human toxicity & kg 1,4-DB eq & $-7.57 \mathrm{E}-03$ & $2.26 \mathrm{E}-02$ & $1.09 \mathrm{E}-03$ & $-3.13 \mathrm{E}-02$ \\
\hline $\begin{array}{l}\text { Photochemical oxidant } \\
\text { formation }\end{array}$ & kg NMVOC & $-2.36 \mathrm{E}-03$ & $4.21 \mathrm{E}-04$ & $8.92 \mathrm{E}-04$ & $-3.67 \mathrm{E}-03$ \\
\hline $\begin{array}{l}\text { Particulate matter } \\
\text { formation }\end{array}$ & kg PM10 eq & $-1.09 \mathrm{E}-03$ & $1.69 \mathrm{E}-04$ & $3.43 \mathrm{E}-04$ & $-1.60 \mathrm{E}-03$ \\
\hline Terrestrial ecotoxicity & kg 1,4-DB eq & 7.19E-06 & $5.33 \mathrm{E}-05$ & $1.75 \mathrm{E}-06$ & $-4.79 \mathrm{E}-05$ \\
\hline Freshwater ecotoxicity & kg 1,4-DB eq & $-4.60 \mathrm{E}-04$ & 7.32E-05 & $9.85 \mathrm{E}-06$ & $-5.44 \mathrm{E}-04$ \\
\hline Marine ecotoxicity & kg 1,4-DB eq & $5.77 \mathrm{E}-05$ & 4.07E-04 & $1.16 \mathrm{E}-05$ & $-3.61 \mathrm{E}-04$ \\
\hline Ionising radiation & $\mathrm{kBq} \mathrm{U} 235 \mathrm{eq}$ & $-8.04 \mathrm{E}-02$ & $7.44 \mathrm{E}-03$ & $3.22 \mathrm{E}-03$ & $-9.10 \mathrm{E}-02$ \\
\hline $\begin{array}{l}\text { Agricultural land } \\
\text { occupation }\end{array}$ & $\mathrm{m} 2 \mathrm{a}$ & $-3.32 \mathrm{E}-01$ & $5.59 \mathrm{E}-04$ & $1.52 \mathrm{E}-02$ & $-3.47 \mathrm{E}-01$ \\
\hline Urban land occupation & $\mathrm{m} 2 \mathrm{a}$ & $-4.57 \mathrm{E}-03$ & $4.50 \mathrm{E}-03$ & $3.55 \mathrm{E}-04$ & $-9.42 \mathrm{E}-03$ \\
\hline $\begin{array}{l}\text { Natural land } \\
\text { transformation }\end{array}$ & $\mathrm{m} 2$ & $-4.13 \mathrm{E}-05$ & $2.73 \mathrm{E}-06$ & $1.24 \mathrm{E}-06$ & $-4.52 \mathrm{E}-05$ \\
\hline Water depletion & $\mathrm{m} 3$ & $-2.40 \mathrm{E}-02$ & $1.92 \mathrm{E}-04$ & $1.02 \mathrm{E}-03$ & $-2.52 \mathrm{E}-02$ \\
\hline Metal depletion & $\mathrm{kg} \mathrm{Fe} \mathrm{eq}$ & $-4.92 \mathrm{E}-02$ & $3.67 \mathrm{E}-04$ & $2.28 \mathrm{E}-03$ & $-5.19 \mathrm{E}-02$ \\
\hline Fossil depletion & $\mathrm{kg}$ oil eq & $-1.77 \mathrm{E}+00$ & 4.01E-02 & 4.82E-02 & $-1.86 \mathrm{E}+00$ \\
\hline
\end{tabular}


Tabel B-3 Milieuprofiel van de energieterugwinning in een AEC van 1000 warmedrankenbekers.

\begin{tabular}{|c|c|c|c|c|c|}
\hline 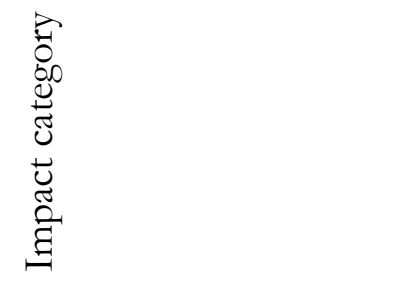 & 节 & تే & 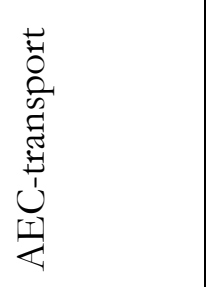 & 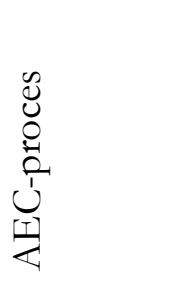 & 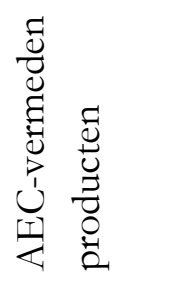 \\
\hline Climate change & $\mathrm{kg} \mathrm{CO} 2 \mathrm{eq}$ & $-2.54 \mathrm{E}+00$ & $7.50 \mathrm{E}-02$ & $9.38 \mathrm{E}-01$ & $-3.56 \mathrm{E}+00$ \\
\hline Ozone depletion & $\mathrm{kg}$ CFC-11 eq & $-1.95 \mathrm{E}-07$ & $1.43 \mathrm{E}-08$ & $1.63 \mathrm{E}-08$ & $-2.26 \mathrm{E}-07$ \\
\hline Terrestrial acidification & $\mathrm{kg} \mathrm{SO} 2 \mathrm{eq}$ & $-2.99 \mathrm{E}-03$ & $2.16 \mathrm{E}-04$ & $1.36 \mathrm{E}-03$ & $-4.57 \mathrm{E}-03$ \\
\hline $\begin{array}{l}\text { Freshwater } \\
\text { eutrophication }\end{array}$ & kg P eq & $-1.21 \mathrm{E}-04$ & $2.02 \mathrm{E}-07$ & $2.73 \mathrm{E}-06$ & $-1.24 \mathrm{E}-04$ \\
\hline Marine eutrophication & $\mathrm{kg} \mathrm{N}$ eq & $-2.69 \mathrm{E}-05$ & $9.35 \mathrm{E}-06$ & $1.31 \mathrm{E}-04$ & $-1.67 \mathrm{E}-04$ \\
\hline Human toxicity & $\mathrm{kg} 1,4-\mathrm{DB}$ eq & 1.24E-01 & $1.52 \mathrm{E}-02$ & $1.56 \mathrm{E}-01$ & $-4.65 \mathrm{E}-02$ \\
\hline $\begin{array}{l}\text { Photochemical oxidant } \\
\text { formation }\end{array}$ & kg NMVOC & $-1.81 \mathrm{E}-03$ & $2.82 \mathrm{E}-04$ & $1.97 \mathrm{E}-03$ & $-4.06 \mathrm{E}-03$ \\
\hline $\begin{array}{l}\text { Particulate matter } \\
\text { formation }\end{array}$ & kg PM10 eq & $-1.11 \mathrm{E}-03$ & $1.13 \mathrm{E}-04$ & $5.47 \mathrm{E}-04$ & $-1.77 \mathrm{E}-03$ \\
\hline Terrestrial ecotoxicity & $\mathrm{kg} 1,4-\mathrm{DB}$ eq & 1.17E-04 & $3.58 \mathrm{E}-05$ & 1.49E-04 & $-6.78 \mathrm{E}-05$ \\
\hline Freshwater ecotoxicity & $\mathrm{kg} 1,4-\mathrm{DB}$ eq & 6.11E-03 & 4.91E-05 & 7.14E-03 & $-1.08 \mathrm{E}-03$ \\
\hline Marine ecotoxicity & $\operatorname{kg} 1,4-\mathrm{DB}$ eq & $1.70 \mathrm{E}-03$ & $2.73 \mathrm{E}-04$ & $2.00 \mathrm{E}-03$ & $-5.74 \mathrm{E}-04$ \\
\hline Ionising radiation & $\mathrm{kBq} U 235 \mathrm{eq}$ & $-9.56 \mathrm{E}-02$ & 4.99E-03 & $2.84 \mathrm{E}-03$ & $-1.03 \mathrm{E}-01$ \\
\hline $\begin{array}{l}\text { Agricultural land } \\
\text { occupation }\end{array}$ & $\mathrm{m} 2 \mathrm{a}$ & $-5.04 \mathrm{E}-01$ & $3.75 \mathrm{E}-04$ & $2.31 \mathrm{E}-03$ & $-5.07 \mathrm{E}-01$ \\
\hline Urban land occupation & $\mathrm{m} 2 \mathrm{a}$ & $-8.43 \mathrm{E}-03$ & $3.02 \mathrm{E}-03$ & $3.75 \mathrm{E}-04$ & $-1.18 \mathrm{E}-02$ \\
\hline $\begin{array}{l}\text { Natural land } \\
\text { transformation }\end{array}$ & $\mathrm{m} 2$ & $-3.83 \mathrm{E}-05$ & $1.83 \mathrm{E}-06$ & $1.11 \mathrm{E}-06$ & $-4.13 \mathrm{E}-05$ \\
\hline Water depletion & $\mathrm{m} 3$ & $-2.60 \mathrm{E}-02$ & $1.29 \mathrm{E}-04$ & 7.61E-03 & $-3.38 \mathrm{E}-02$ \\
\hline Metal depletion & $\mathrm{kg} \mathrm{Fe} \mathrm{eq}$ & $-7.39 \mathrm{E}-02$ & 2.46E-04 & $1.79 \mathrm{E}-03$ & $-7.60 \mathrm{E}-02$ \\
\hline Fossil depletion & kg oil eq & $-1.13 \mathrm{E}+00$ & $2.69 \mathrm{E}-02$ & $2.36 \mathrm{E}-02$ & $-1.18 \mathrm{E}+00$ \\
\hline
\end{tabular}

